\title{
MORPHOLOGICAL, GEOGRAPHICAL, AND ECOLOGICAL DIFFERENTIATION IN THE CAREX WILLDENOWII COMPLEX (CYPERACEAE) ${ }^{1}$
}

\author{
Robert F. C. Naczi, ${ }^{2,3}$ Anton A. Reznicek, ${ }^{4}$ And Bruce A. Ford ${ }^{5}$ \\ ${ }^{3}$ Department of Biological Sciences, Northern Kentucky University, Highland Heights, Kentucky 41099-0400; \\ ${ }^{4}$ University of Michigan Herbarium, North University Building, Ann Arbor, Michigan 48109-1057; and \\ ${ }^{5}$ Department of Botany, University of Manitoba, Winnipeg, Manitoba R3T 2N2, Canada
}

\begin{abstract}
Field studies as well as principal components analysis and analyses of variance of specimen measurements revealed morphologic variation within Carex willdenowii correlated with differences in geographical distribution and habitat characteristics. C. willdenowii is actually a complex of three species, C. basiantha Steudel, C. willdenowii Willdenow, and $C$. superata Naczi, Reznicek, \& B.A. Ford, sp. nov. Carex basiantha is a calciphile of moist forests in the southern United States. It has relatively long culms and terminal spikes with long staminate portions. Carex willdenowii is a calcifuge of dry forests in the northeastern United States and immediately adjacent Canada. It has relatively long culms and terminal spikes with short staminate portions. Carex superata is a facultative calciphile of moist to dry forests of the southeastern United States. It has relatively short culms and terminal spikes with long staminate portions. Synonymies, typifications, descriptions, and citations of representative specimens are provided for each species, along with an identification key. The recognition of previously unsuspected diversity in a species from a region with a relatively well-known flora suggests the systematics of other common, widespread, and morphologically divergent species should be investigated.
\end{abstract}

Key words: Carex section Phyllostachys; Cyperaceae; phytogeography; principal components analysis; species delimitation.

Carex section Phyllostachys (J. Carey) L.H. Bailey is a small and morphologically distinctive group of sedges endemic to North American forests and forest openings. In the most recent taxonomic study of the section, Catling, Reznicek, and Crins (1993) included six species: $C$. backii Boott; C. jamesii Schwein.; C. juniperorum Catling, Reznicek, \& Crins; C. latebracteata Waterf.; C. saximontana Mack.; and C. willdenowii Willd. Members of the section possess winged culms and peduncles, both of which are dilated at their apices; androgynous spikes, with the lateral ones (lacking in $C$. latebracteata) arising from the base of the plant on capillary peduncles; large and often leaf-like scales subtending at least the lower perigynia in each spike; and beaked perigynia with entire orifices. At least some of these features are probably autapomorphies diagnosing a monophyletic section, though the polarization of character states is a very uncertain and difficult endeavor in a genus so large $(\sim 2000$ species $)$ and whose phylogeny is so poorly understood (Crins, 1990; Reznicek, 1990).

\footnotetext{
${ }^{1}$ Manuscript received 20 August 1996; revision accepted 21 July 1997.

The authors thank Peter W. Ball, Charles T. Bryson, Paul M. Catling, and Julian R. Starr for providing useful comments on the manuscript; Lawrence R. Borne, Charles T. Bryson, John D. Freeman, Susan A. Reznicek, and Thomas F. Wieboldt for assisting with field work; the curators of AUA, BEREA, BH, CM, CU, GH, IBE, ILLS, KNK, MICH, MO, MSC, NA, NEBC, NCU, NY, OS, P, PAC, PENN, PH, US, USCH, VDB, WIN and Charles Bryson and Steven R. Hill for loans of herbarium specimens or assistance during visits; Susan A. Reznicek for preparing the drawing; National Science Foundation grant BSR9001260 (to Naczi), a Natural Sciences and Engineering Research Council of Canada operating and equipment grant (to Ford), and the Department of Botany and Faculty of Science of the University of Manitoba (to Ford) for funding portions of this work.

${ }^{2}$ Author for correspondence.
}

Carex willdenowii is a readily recognized species and one of the most common members of sect. Phyllostachys. It is relatively widespread, occurring from Massachusetts to Ohio and southern Indiana south to Georgia and Texas (Gleason and Cronquist, 1991). It is unique within sect. Phyllostachys in possessing asynchronous spike production and the combination of perigynium bodies that gradually taper to beaks and lowest pistillate scales $<2.5 \mathrm{~mm}$ wide. All other species in the section have synchronous spike production and perigynium bodies abruptly contracted to beaks or, in the case of $C$. backii, perigynium bodies gradually tapering to beaks and the lowest pistillate scales wider than $2.5 \mathrm{~mm}$. Other diagnostic features of $C$. willdenowii include narrow leaf blades (widest leaf per plant $2.0-4.6 \mathrm{~mm}$ wide) and long perigynium beaks (1.7-6.4 mm long). It shares the combination of narrow leaf blades, narrow pistillate scales, and long perigynium beaks only with $C$. jamesii. Based on the results of character compatibility analysis, Crins (1990) suggested $C$. jamesii is the sister species of $C$. willdenowii. In addition to the features unique to it, $C$. willdenowii differs from C. jamesii in possessing longer staminate scales [1.4-4.1 $\mathrm{mm}$ vs. $1.0-1.3(-2.5) \mathrm{mm}$ for $C$. jamesii] that are obtuse (vs. subtruncate) and oblong achenes (vs. orbicular: length/width ratio of 1.2-2.2 for C. willdenowii achenes vs. 1.1-1.3 for C. jamesii).

Since $C$. willdenowii occurs near centers of early North American botanical study and is common and so distinctive, it is not surprising that it was the first species of the section to be described (Willdenow, 1805). Nearly all later botanists have accepted it as a "good species" (e.g., de Schweinitz, 1825; Dewey, 1825; Torrey, 1836; Kunth, 1837; Boott, 1858; Bailey, 1886; Kükenthal, 1909; Mackenzie, 1935; Fernald, 1950; Gleason and Cronquist, 1991). Consequently, its taxonomy has been uncontro- 
versial and its nomenclatural history uncomplicated. The only name at the rank of species that relates to the nomenclature of $C$. willdenowii is $C$. basiantha Steudel (1855), described from Louisiana. Later botanists placed this name into the synonymy of $C$. willdenowii (Bailey, 1889, 1894a; Kükenthal, 1909; Mackenzie, 1935). Two varieties have been described within $C$. willdenowii. Bailey (1894b) described C. willdenowii var. pauciflora for plants from Texas with fewer pistillate flowers than $C$. willdenowii var. willdenowii. Mackenzie (1935) regarded this variety as undeserving of taxonomic recognition. More recently, Hermann (1954) described $C$. willdenowii var. megarrhyncha for plants from Alabama, Georgia, and Louisiana having longer perigynia with longer beaks and larger achenes than the typical variety. Later authors have accepted $C$. willdenowii var. megarrhyncha (e.g., Soil Conservation Service, 1982; Anderson, 1989; Kartesz, 1994). The systematics of $C$. willdenowii never has been the subject of a thorough investigation, though Holm (1900) studied its anatomy and inflorescence morphology.

Our field work on Carex willdenowii in the eastern United States has revealed substantial variation in the morphological features that correlates with geography and ecology. We have noted three different morphologies and hypothesize that $C$. willdenowii as currently recognized is a complex of three species, $C$. willdenowii, $C$. basiantha, and $C$. superata. In this paper, we answer the following questions in order to better understand this complex: (1) how many taxonomic entities actually exist in the complex?, (2) how are they best distinguished morphologically?, (3) what ranks are appropriate for them?, (4) what geographical features distinguish them?, (5) what ecological features distinguish them? This is the first of two papers exploring the taxonomy and genetic relationships among taxa in the $C$. willdenowii complex.

\section{MATERIALS AND METHODS}

We investigated the morphology, geography, and ecology of the $C$. willdenowii complex in the field on several trips during 1988-1997. The field work included specimen collecting, soil sampling, and gathering of ecological data at as many sites as possible throughout the geographic range of this complex. The field trips were in 16 states of the eastern United States: Alabama, Arkansas, Florida, Georgia, Kentucky, Louisiana, Maryland, Mississippi, New York, Ohio, Oklahoma, Pennsylvania, South Carolina, Tennessee, Texas, and Virginia.

We also borrowed specimens from or visited the following 27 herbaria: AUA, BEREA, BH, CM, CU, GH, IBE, ILLS, KNK, MICH, MO, MSC, NA, NEBC, NCU, NY, OS, P, PAC, PENN, PH, US, USCH, VDB, WIN, ctb, and srh. Abbreviations of herbaria are those of Holmgren, Holmgren, and Barnett (1990) except for Charles T. Bryson herbarium (ctb) and Steven R. Hill herbarium (srh). In total, we studied over 925 specimens of the $C$. willdenowii complex in the course of this study.

Morphology - We selected 92 of the specimens available to us as a representative subset to measure for univariate and multivariate statistical analyses. We chose mature, complete, and ample specimens that exhibited the full range of morphologic variation of the $C$. willdenowii complex and that originated from throughout the geographic range of the complex. We measured 12 continuous and two discrete characters (Table 1) on each of these specimens. Each specimen we measured is denoted by a superscript asterisk in the lists of representative specimens below.
TABLE 1. Morphological characters, with their abbreviations, measured on herbarium specimens of the Carex willdenowii complex. Characters marked with an asterisk are those included in the principal components analysis.

Continuous characters

1. Height of tallest culm, including terminal spike (CLMHT)*

2. Height of shoot bearing tallest culm (SHTHT)

3. Width of widest leaf blade (WLFW)*

4. Length of longest staminate portion of terminal spike (MSPL)*

5. Length of staminate scale, from middle region of staminate portion of terminal spike (MSCL)*

6. Length of longest peduncle of lateral spike (PDCLL)

7. Length of perigynium (PERIGL)

8. Width of perigynium (PERIGW)

9. Length of perigynium beak (PERIGBKL)*

10. Length of achene (ACHNL)*

11. Width of achene (ACHNW)*

12. Height of culm/height of shoot (RCLM)*

Discrete characters

13. Number of leaves and/or bracts on shoot bearing tallest culm (LFNO)

14. Number of perigynia in terminal spike (PERIGNO)

To detect groups among the specimens and extract the variables that best diagnose these groups, we used principal components analysis (PCA). Before conducting the analysis, we standardized all measurements so each variable would have a mean of 0 and a standard deviation of 1 . For the PCA, we included only continuous characters. To avoid weighting characters, we excluded characters that are probably genetically redundant, as revealed by high values for the Pearson correlation coefficient between all possible pairs of characters. Exclusion of four genetically redundant and two discrete characters resulted in the remaining eight characters being included in the PCA (Table 1).

We assessed the degree to which the groups detected in the PCA differed among themselves, character by character, by analyzing each of the measured variables with one-way analysis of variance (ANOVA) with the Tukey Honestly Significantly Different test for multiple comparisons of means. Because the variances of several variables are heterogeneous (as determined by the Bartlett chi-square test for homogeneity of group variances), we transformed the data with the common logarithm before conducting the ANOVA.

We performed all statistical analyses with SYSTAT version 5.1 (Wilkinson, 1989) on an Apple ${ }^{\circledR}$ Macintosh ${ }^{\circledR}$ computer.

In order to apply the available names to the groups revealed through PCA and ANOVA, we studied the holotypes of the names. Of these specimens, only the holotype of $C$. willdenowii var. megarrhyncha was suitable for measuring. We applied all other names by comparing their holotypes with the specimens of the PCA and ANOVA groups.

Geography-To determine the geographic range of each of the groups revealed through the morphologic studies, we used herbarium specimen collection data to plot their distributions on outline maps. Each point on these maps is based on at least one herbarium specimen. From these voucher-based distribution maps, we depicted the combined ranges of members of the $C$. willdenowii complex on one map to reveal regions of sympatry and allopatry among them.

The terminology of physiographic provinces and their sections follows Fenneman (1938) and Pirkle and Yoho (1977).

Ecology-To aid in characterizing the habitats of members of the $C$. willdenowii complex, we collected soil samples from four populations from widely separate portions of the geographic range of each of the entities of the complex. For each population, we sampled approximately equal amounts of soil from the rhizospheres of three plants. Each sampled plant was at least $10 \mathrm{~m}$ from another sampled plant. The three samples were mixed by hand and a portion of the resulting pooled 


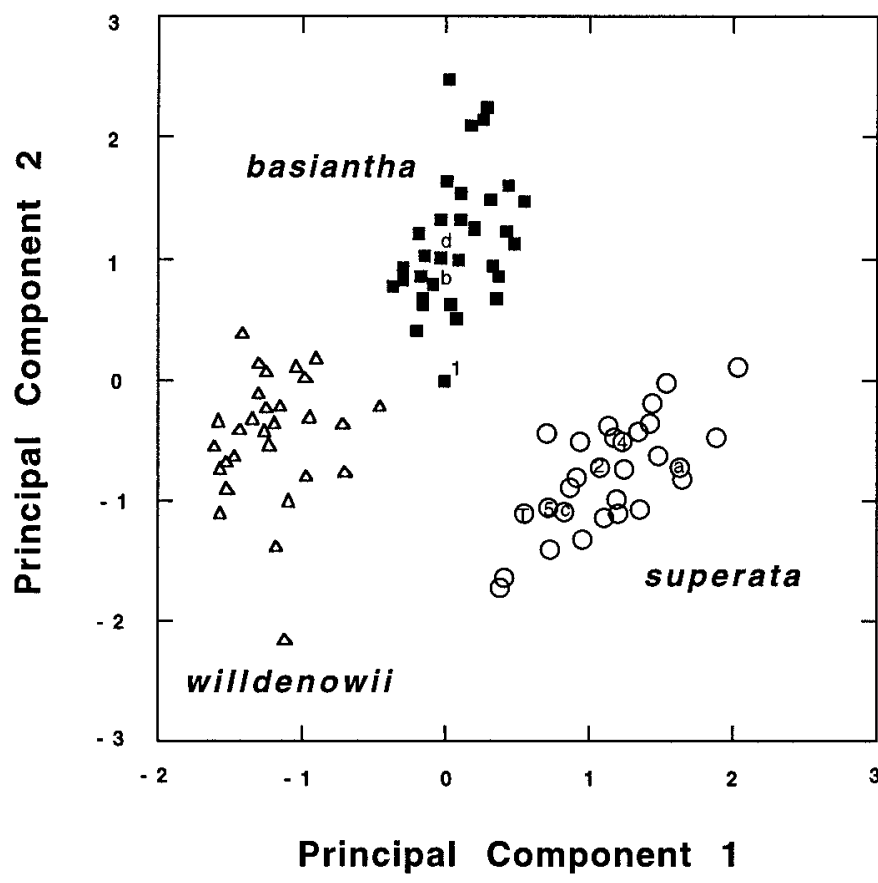

Fig. 1. Scatter plot of the scores of principal component 2 vs. principal component 1 from PCA of the measurements of members of the Carex willdenowii complex. Squares represent specimens of C. basiantha, triangles represent $C$. willdenowii, and circles represent $C$. superata. The encircled " $T$ " represents the holotype of $C$. willdenowii var. megarrhyncha. Numbered symbols represent paratypes of $C$. willdenowii var. megarrhyncha. Symbols with lowercase letters represent specimens Hermann (1954) considered transitional between C. willdenowii var. megarrhyncha and $C$. willdenowii var. willdenowii.

sample was submitted to the Michigan State University Soil Testing Laboratory where calcium, iron, magnesium, phosphorus, and potassium concentrations; $\mathrm{pH}$; percentage organic matter; and particle size distribution (percentage sand, percentage silt, and percentage clay) were determined. Each of the voucher specimens representing the populations from which soil samples were gathered is denoted by a superscript "s" in the lists of representative specimens below.

For each population studied in the field, we noted vascular plant associates. Closely associated vascular plant species are those that grew within $10 \mathrm{~m}$ of a plant of the C. willdenowii complex at more than onethird of all sites in which we observed that member of the complex.

We also surveyed all localities of a member of the $C$. willdenowii complex for other members of the complex. We consider co-occurrences of different members of the complex at a given site, whether intermingled or slightly separated, to be examples of syntopy.

\section{RESULTS}

Morphology - A scatter plot of the scores of principal components 1 and 2 depicts three distinct groups (Fig. 1). Component 1 provides complete separation of $C$. willdenowii from $C$. superata, while $C$. basiantha is separated on component 2. No subgroupings within these three groups are evident. Together, the first two components explain $77 \%$ of the variance within the data set, with component 1 accounting for 56\% and component 2 accounting for $21 \%$. The third principal component accounts for only $7 \%$ of the total variance and affords no separation of groups. All of the variables employed in the PCA have relatively high loadings (absolute values >
TABLE 2. Loadings for the first two principal components from PCA of specimens of the Carex willdenowii complex. Character abbreviations correspond to those in Table 1.

\begin{tabular}{lcc}
\hline \hline Character & Component 1 & Component 2 \\
\hline CLMHT & -0.42 & 0.84 \\
WLFW & 0.77 & -0.16 \\
MSPL & 0.65 & 0.66 \\
MSCL & 0.84 & 0.099 \\
PERIGBKL & 0.92 & -0.13 \\
ACHNL & 0.77 & 0.43 \\
ACHNW & 0.72 & 0.20 \\
RCLM & -0.82 & 0.47 \\
\hline
\end{tabular}

0.6) on at least one of the first two components (Table 2 ). The variables with the highest loadings on component 1 are PERIGBKL, MSCL, and RCLM, in descending order (abbreviations are those listed in Table 1). On component 2, CLMHT, MSPL, and RCLM had the highest loadings. A plot of CLMHT vs. PERIGBKL indicates slight overlap among the three groups for the variables of highest loading for each component (Fig. 2). In addition, this plot demonstrates the greater value of the PCA plot in portraying the distinctness of each of the three groups.

Like the PCA, the ANOVA supports the existence of three groups in the $C$. willdenowii complex. Though the measurements of many characters possess considerable variability and the ranges of the measurements overlap for many characters, at least two of the three groups have significantly different means for all 14 measured variables (Table 3). For eight of these characters, all three

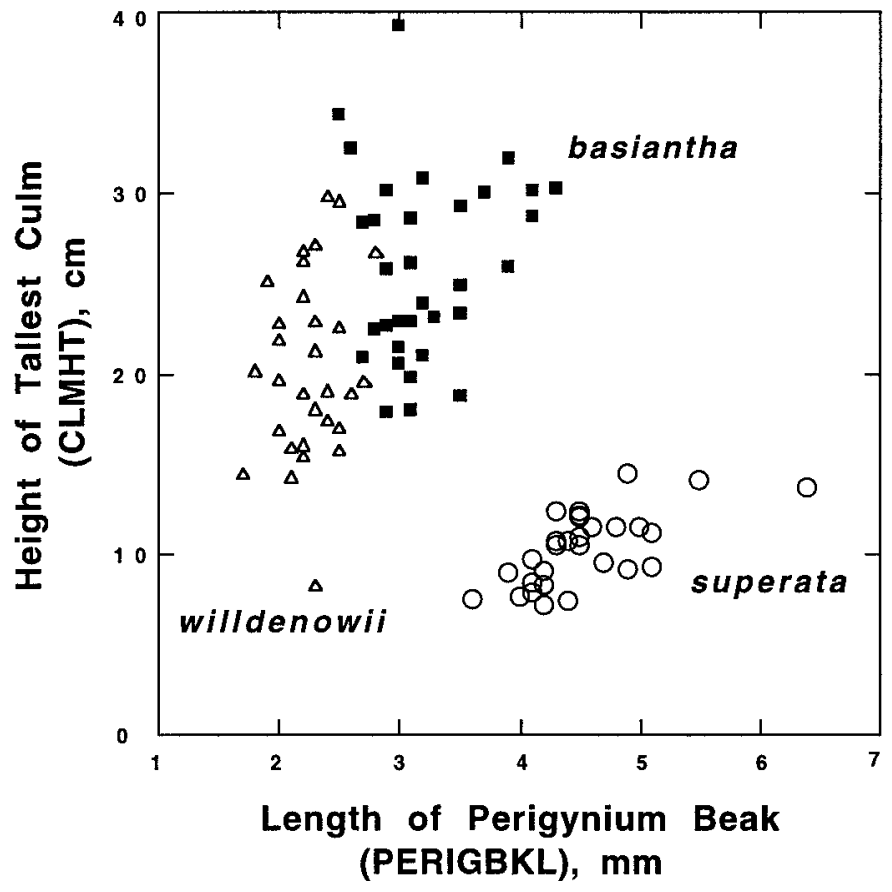

Fig. 2. Scatter plot of measurements of the variable having the highest loading on principal component 2 (height of the tallest culm) vs. on component 1 (length of perigynium beak) for the members of the Carex willdenowii complex. Squares represent specimens of $C$. basiantha, triangles represent $C$. willdenowii, and circles represent $C$. superata. 
TABLE 3. Means $\pm 1 \mathrm{SD}$ and ranges for morphological characters measured for Carex willdenowii complex. Character abbreviations correspond to those in Table 1. All measurements are in millimeters, except character 12 (a ratio) and characters 13-14 (counts). $N=$ sample size. Within a row, means with different superscripts differ significantly (ANOVA, $P<0.05$ ).

\begin{tabular}{|c|c|c|c|c|}
\hline Character & $\begin{array}{c}\text { C. basiantha } \\
(N=33)\end{array}$ & $\begin{array}{l}\text { C. superata } \\
(N=29)\end{array}$ & $\begin{array}{l}\text { C. willdenowii } \\
(N=30)\end{array}$ & $\begin{array}{c}\text { ANOVA } \\
F\end{array}$ \\
\hline 1. CLMHT & $\begin{array}{c}259^{\mathrm{a}} \pm 51.1 \\
(180-393)\end{array}$ & $\begin{array}{r}103^{\mathrm{b}} \pm 21 \\
(71-144)\end{array}$ & $\begin{array}{r}203^{c} \pm 51 \\
\quad(82-297)\end{array}$ & 140 \\
\hline 2. SHTHT & $\begin{array}{c}417^{\mathrm{a}} \pm 80.1 \\
(288-553)\end{array}$ & $\begin{array}{c}395^{\mathrm{a}} \pm 95.2 \\
(241-646)\end{array}$ & $\begin{array}{c}302^{\mathrm{b}} \pm 97.5 \\
(185-642)\end{array}$ & 14 \\
\hline 3. WLFW & $\begin{array}{c}3.0^{\mathrm{a}} \pm 0.37 \\
(2.4-3.7)\end{array}$ & $\begin{array}{c}3.6^{\mathrm{b}} \pm 0.51 \\
(2.7-4.6)\end{array}$ & $\begin{array}{c}2.6^{c} \pm 0.32 \\
(2.0-3.2)\end{array}$ & 45 \\
\hline 4. MSPL & $\begin{array}{c}18.8^{\mathrm{a}} \pm 2.75 \\
(12.7-25.6)\end{array}$ & $\begin{array}{c}15.0^{\mathrm{b}} \pm 2.7 \\
(9.6-20.1)\end{array}$ & $\begin{array}{c}7.5^{\mathrm{c}} \pm 1.1 \\
(4.9-10.3)\end{array}$ & 260 \\
\hline 5. MSCL & $\begin{array}{c}2.7^{\mathrm{a}} \pm 0.27 \\
(2.2-3.3)\end{array}$ & $\begin{array}{c}3.0^{\mathrm{b}} \pm 0.31 \\
(2.5-3.4)\end{array}$ & $\begin{array}{c}2.2^{\mathrm{c}} \pm 0.26 \\
1.7-2.6\end{array}$ & 69 \\
\hline 6. PDCLL & $\begin{array}{r}144^{\mathrm{a}} \pm 43 \\
(76-252)\end{array}$ & $\begin{array}{c}68^{b} \pm 28 \\
(0-113)\end{array}$ & $\begin{array}{c}115^{\mathrm{c}} \pm 41 \\
(28-221)\end{array}$ & 31 \\
\hline 7. PERIGL & $\begin{array}{c}6.9^{\mathrm{a}} \pm 0.67 \\
(5.8-8.0)\end{array}$ & $\begin{array}{r}8.3^{\mathrm{b}} \pm 0.82 \\
(7.0-10.8)\end{array}$ & $\begin{array}{l}5.3^{\mathrm{c}} \pm 0.45 \\
(4.5-6.5)\end{array}$ & 170 \\
\hline 8. PERIGW & $\begin{array}{c}1.7^{\mathrm{a}} \pm 0.14 \\
(1.4-2.0)\end{array}$ & $\begin{array}{c}1.8^{\mathrm{a}} \pm 0.20 \\
(1.5-2.3)\end{array}$ & $\begin{array}{c}1.5^{\mathrm{b}} \pm 0.13 \\
(1.3-1.7)\end{array}$ & 23 \\
\hline 9. PERIGBKL & $\begin{array}{c}3.2^{\mathrm{a}} \pm 0.46 \\
(2.5-4.3)\end{array}$ & $\begin{array}{c}4.5^{\mathrm{b}} \pm 0.55 \\
(3.6-6.4)\end{array}$ & $\begin{array}{c}2.3^{c} \pm 0.26 \\
(1.7-2.8)\end{array}$ & 240 \\
\hline 10. $\mathrm{ACHNL}$ & $\begin{array}{c}2.8^{\mathrm{a}} \pm 0.23 \\
(2.4-3.4)\end{array}$ & $\begin{array}{c}2.8^{\mathrm{a}} \pm 0.23 \\
(2.1-3.3)\end{array}$ & $\begin{array}{c}2.3^{\mathrm{b}} \pm 0.19 \\
(1.8-2.6)\end{array}$ & 67 \\
\hline 11. ACHNW & $\begin{array}{c}1.6^{\mathrm{a}} \pm 0.14 \\
(1.3-1.9)\end{array}$ & $\begin{array}{c}1.7^{\mathrm{a}} \pm 0.18 \\
(1.4-2.1)\end{array}$ & $\begin{array}{c}1.4^{\mathrm{b}} \pm 0.11 \\
(1.2-1.6)\end{array}$ & 34 \\
\hline 12. RCLM & $\begin{array}{c}0.62^{\mathrm{a}} \pm 0.061 \\
(0.49-0.79)\end{array}$ & $\begin{array}{c}0.27^{\mathrm{b}} \pm 0.051 \\
(0.18-0.38)\end{array}$ & $\begin{array}{c}0.69^{\mathrm{c}} \pm 0.11 \\
(0.41-0.87)\end{array}$ & 350 \\
\hline 13. LFNO & $\begin{array}{c}4^{\mathrm{a}} \pm 0.6 \\
(3-5)\end{array}$ & $\begin{array}{c}3^{a} \pm 0.6 \\
(2-5)\end{array}$ & $\begin{array}{r}6^{\mathrm{b}} \pm 1 \\
(3-9)\end{array}$ & 41 \\
\hline 14. PERIGNO & $\begin{array}{c}3^{\mathrm{a}} \pm 0.9 \\
(2-6)\end{array}$ & $\begin{array}{c}3^{\mathrm{a}} \pm 0.9 \\
(2-6)\end{array}$ & $\begin{array}{r}6^{\mathrm{b}} \pm 1 \\
(3-9)\end{array}$ & 67 \\
\hline
\end{tabular}

means are significantly different from each other. The variables that are the best for distinguishing the members of the $C$. willdenowii complex, based on high $F$ values, are RCLM, MSPL, and PERIGBKL, in descending order. For all six variables for which two groups have statistically indistinguishable means (SHTHT, PERIGW, ACHNL, ACHNW, LFNO, and PERIGNO), the similar means are shared by $C$. basiantha and $C$. superata. In five other features, $C$. basiantha is intermediate between C. willdenowii and C. superata (WLFW, MSCL, PERIGL, PERIGBKL, and RCLM).

All three species identified in the PCA and ANOVA are distinguished by a number of characters. Those specimens with high values for CLMHT, high MSPL, and high RCLM were referable to Carex basiantha. Plants with low values for PERIGBKL, low MSCL, low MSPL, and high RCLM were referable to Carex willdenowii. The third group, with high PERIGBKL, high MSCL, low CLMHT, high MSPL, and low RCLM was C. superata (C. willdenowii var. megarrhyncha). The holotype of $C$. willdenowii var. megarrhyncha (Smith \& Duncan 4872, US!) falls clearly within this final group of specimens (Fig. 1).

Several additional characters also serve to distinguish these species (Table 3). Tall shoots (SHTHT) and long peduncles (PDCLL) distinguish $C$. basiantha. Carex willdenowii has the lowest values for SHTHT, the narrowest leaf blades (WLFW), and the shortest and narrowest perigynia and achenes (PERIGL, PERIGW, ACHNL, and ACHNW). High values for WLFW and PERIGL, but low values for PDCLL, are associated with $C$. superata.
Two discrete characters are also useful in distinguishing members of the complex (Table 3). Carex basiantha and $C$. superata usually have fewer leaves and/or bracts per shoot than $C$. willdenowii (LFNO). Carex basiantha and $C$. superata also have fewer perigynia per spike than C. willdenowii (PERIGNO). The terminal spikes of the first two species usually have 2-4 perigynia, whereas the latter species usually has 5-7 perigynia. The lateral spikes are similar to the terminal ones in the number of perigynia they bear. Thus, a substantial number of plants of the $C$. willdenowii complex have only 2-4 perigynia per spike, in spite of claims of some previous authors (Kükenthal, 1909; Mackenzie, 1935; Catling, Reznicek, and Crins, 1993) in identification keys that $C$. willdenowii usually has 3-9 perigynia per spike (vs. usually 2-3 for C. jamesii).

A few qualitative characters that could not be included in the numerical analyses were also correlated with the taxonomic entities distinguished in this analysis. Carex basiantha usually has dark brown shoot bases and widely spreading to nodding culms and peduncles. The shoot bases of $C$. willdenowii are usually tan and this species has widely spreading culms and peduncles. Carex superata is the only species of the complex to have predominantly erect or slightly spreading culms and peduncles, probably due to their shortness. Its shoot bases are usually dark brown.

Geography-Carex basiantha is frequent throughout most of its range of the southeastern United States. It ranges from southeastern North Carolina west to north- 


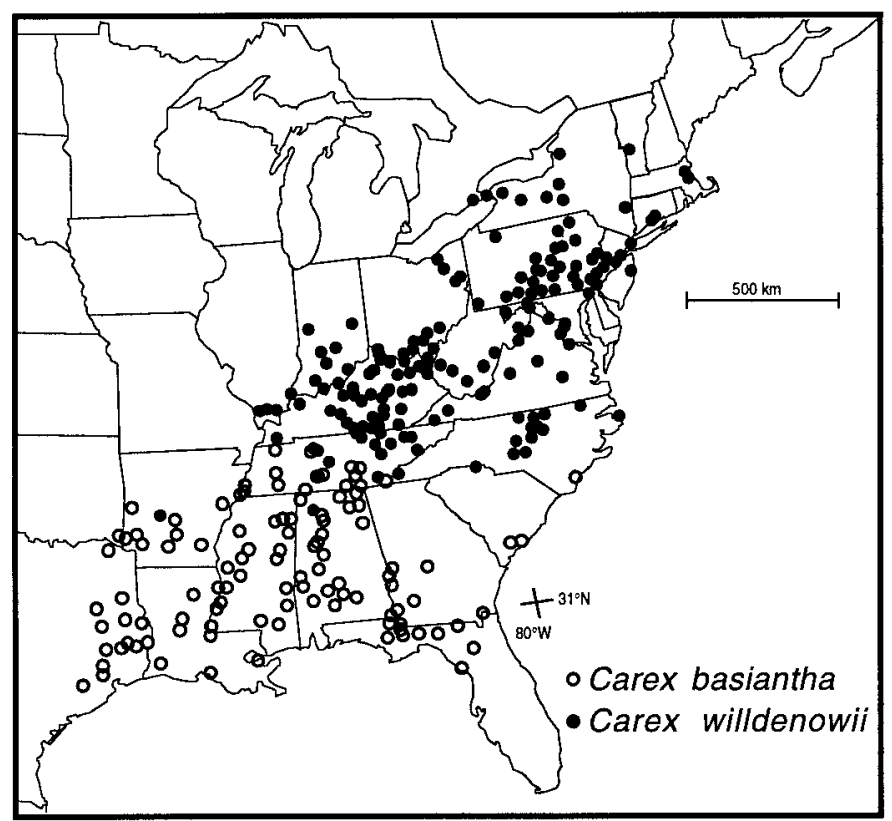

Fig. 3. Geographical distribution of Carex basiantha and Carex willdenowii.

western Tennessee, central Arkansas, and southeastern Oklahoma south to northern Florida, southern Alabama, southern Mississippi, southern Louisiana, and southeastern Texas (Fig. 3). Most of the range of C. basiantha lies in the Coastal Plain, with additional portions in the Appalachian Plateaus, Interior Low Plateaus, Ouachita, and, very rarely, in the Ridge and Valley physiographic provinces. In most of Georgia, most of Alabama, and central Tennessee, it is sympatric with C. superata (Figs. 4, 5). Only two small portions of the range of $C$. basiantha, in southern Tennessee and adjacent northern Alabama and then central Arkansas, overlap that of $C$. willdenowii. Carex basiantha is the only member of the $C$. willdenowii complex to occur in much of the southeastern United States, especially for most of the region from Mississippi and western Tennessee westward.

Carex superata is infrequent and local within its relatively small range: western Virginia and southern Kentucky south to northern Florida and southern Alabama (Fig. 4). The physiographic provinces included in this range are the Coastal Plain, Piedmont, Appalachian Plateaus, Interior Low Plateaus, and a very small part of the Ridge and Valley. Most of its range overlaps a portion of that of C. basiantha (Fig. 5). The northern portion of the range of $C$. superata overlaps the southwestern part of the range of $C$. willdenowii. Only in eastern Georgia and most of Piedmont South Carolina does C. superata appear to be the only member of the $C$. willdenowii complex to occur.

Carex willdenowii is frequent in most of its range in the northeastern United States and adjacent Canada from southern Vermont, northern New York, and southern Ontario south and west to northernmost South Carolina and northern Alabama (Fig. 3). In addition, it is disjunct in Garland County, Arkansas. Known populations in Canada are only two, both in Ontario just south of the western end of Lake Ontario. Carex willdenowii occurs in

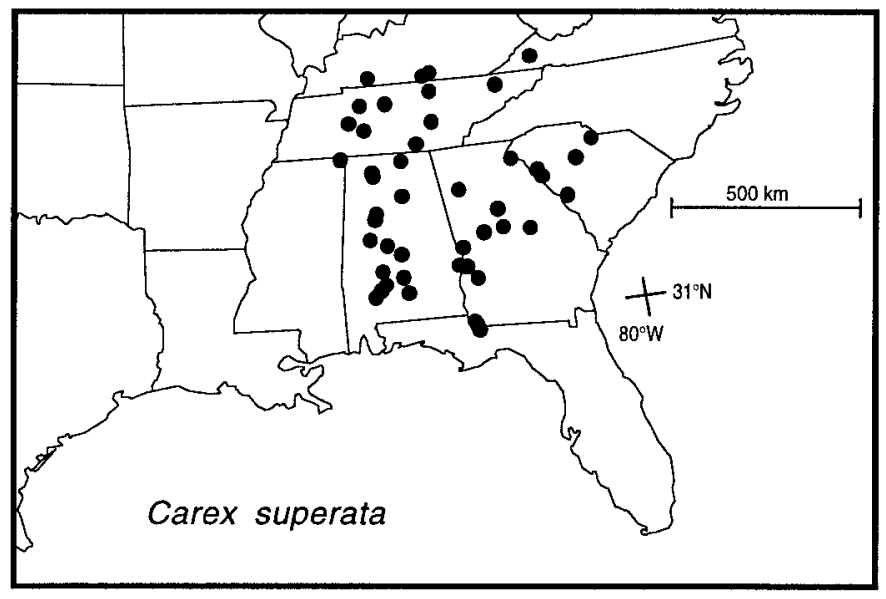

Fig. 4. Geographical distribution of Carex superata.

nine physiographic provinces, including the Piedmont, Appalachian Plateaus, and Interior Low Plateaus. It is very rare in the Coastal Plain. The Arkansas disjunction, where only one population is known, is in the eastern portion of the Ouachita physiographic province. This species is the only member of the complex known in Canada and most of the northeastern United States (Fig. 5). It is sympatric with the other members of the complex only in the southern portions of its range. In northernmost South Carolina and from southern Kentucky south to northernmost Alabama, its range overlaps that of C. superata. Southern Tennessee and adjacent northern Alabama and the Ouachita Mountains of Arkansas are the only places where $C$. willdenowii is sympatric with $C$. basiantha. A small region of southern Tennessee and adjacent northern Alabama in the Interior Low Plateaus is the only place where all three taxa of the $C$. willdenowii complex are sympatric.

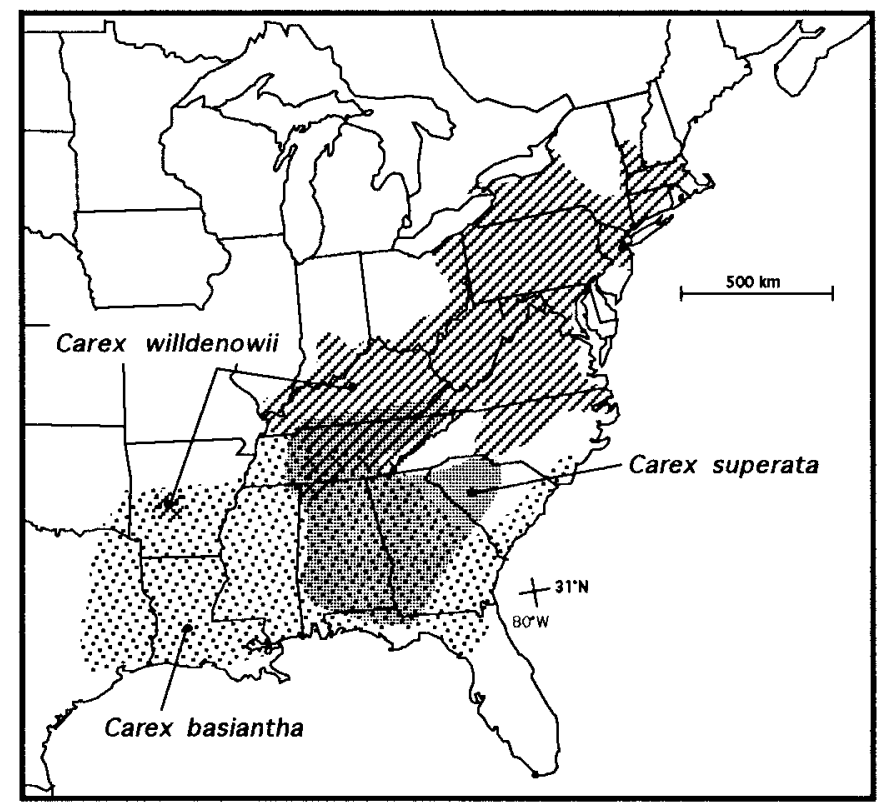

Fig. 5. Regions of sympatry and allopatry of members of the Carex willdenowii complex. 
TABLE 4. Means $\pm 1 \mathrm{SD}$ and ranges for values of soil properties of members of the Carex willdenowii complex. $N=$ sample size.

\begin{tabular}{lccc}
\hline \hline Property & $\begin{array}{c}\text { C. basiantha } \\
(N=4)\end{array}$ & $\begin{array}{c}\text { C. superata } \\
(N=4)\end{array}$ & $\begin{array}{c}\text { C. willdenowii } \\
(N=4)\end{array}$ \\
\hline 1. $\mathrm{pH}$ & $6.4 \pm 0.58$ & $5.6 \pm 0.85$ & $5.0 \pm 0.47$ \\
& $(5.8-6.9)$ & $(4.7-6.7)$ & $(4.6-5.5)$ \\
2. $\mathrm{Ca}\left(\mathrm{g} / \mathrm{m}^{2}\right)$ & $566 \pm 239$ & $367 \pm 131$ & $129 \pm 59$ \\
& $(291-872)$ & $(189-496)$ & $(59-198)$ \\
3. $\mathrm{Fe}\left(\mathrm{g} / \mathrm{m}^{2}\right)$ & $3.1 \pm 2.1$ & $7.2 \pm 4.7$ & $22 \pm 13$ \\
& $(1.1-6.1)$ & $(1.3-13)$ & $(7.6-37)$ \\
4. $\mathrm{K}\left(\mathrm{g} / \mathrm{m}^{2}\right)$ & $19 \pm 8.5$ & $57 \pm 29$ & $13 \pm 7.9$ \\
& $(9.4-31)$ & $(31-87)$ & $(4.7-19)$ \\
5. $\mathrm{Mg}\left(\mathrm{g} / \mathrm{m}^{2}\right)$ & $51 \pm 11$ & $76 \pm 41$ & $31 \pm 22$ \\
& $(39-65)$ & $(39-129)$ & $(11-57)$ \\
6. $\mathrm{P}\left(\mathrm{g} / \mathrm{m}^{2}\right)$ & $1.9 \pm 1.9$ & $2.2 \pm 1.2$ & $2.1 \pm 0.43$ \\
& $(0.90-4.7)$ & $(0.90-3.6)$ & $(1.8-2.7)$ \\
7. Organic matter $(\%)$ & $6.1 \pm 2.1$ & $7.1 \pm 1.2$ & $3.3 \pm 0.78$ \\
& $(4.2-9.0)$ & $(5.3-7.8)$ & $(2.5-4.3)$ \\
8. Sand $(\%)$ & $37.3 \pm 14.5$ & $39.4 \pm 14.2$ & $31.0 \pm 10.7$ \\
& $(21.0-49.8)$ & $(25.8-55.1)$ & $(15.1-37.8)$ \\
9. Silt $(\%)$ & $35.8 \pm 18.3$ & $26.9 \pm 4.44$ & $43.3 \pm 8.02$ \\
& $(16.8-60.7)$ & $(20.3-30.0)$ & $(36.0-54.7)$ \\
10. Clay $(\%)$ & $26.9 \pm 9.24$ & $33.7 \pm 12.7$ & $25.7 \pm 3.42$ \\
& $(18.3-36.2)$ & $(16.5-45.4)$ & $(22.2-30.2)$ \\
\hline
\end{tabular}

Ecology-Carex basiantha inhabits mesic to wet-mesic deciduous forests. It usually grows near streams (often rivers), most often low on slopes just above floodplains. Soils in which it grows are usually acidic to subneutral (pH 5.8-6.9) loams, silt loams, and clay loams high in calcium and low in iron (Table 4). The forests in which it grows usually possess diverse herbaceous floras. The most frequent vascular plant associates of $C$. basiantha are Aesculus pavia L., Arundinaria gigantea (Walt.) Muhl., Carex abscondita Mackenzie, C. amphibola Steud., C. blanda Dewey, C. laxiflora Lam. var. serrulata F.J. Herm., C. oxylepis Torr. \& Hook., C. rosea Willd., Cercis canadensis L., Hexastylis arifolia (Michx.) Small, Podophyllum peltatum L., Polystichum acrostichoides (Michx.) Schott, and Sanguinaria canadensis L. Noteworthy as infrequent associates (but observed by us at several sites) are the calciphiles Carex jamesii Schwein. and $C$. oligocarpa Willd. Occasionally, C. basiantha occurs at sites with $C$. superata (Table 5).

Carex superata grows in mesic to (occasionally) drymesic deciduous forests. It usually grows in ravines on slopes above small streams. Its substrates are acidic to subneutral ( $\mathrm{pH}$ 4.7-6.7) clay loams, sandy clay loams, and clays high in potassium and magnesium (Table 4).
The calcium content of its soils ranges widely. Carex superata appears to be a facultative calciphile. Its habitats are usually relatively open forests with few herbs. Close vascular plant associates include Carex digitalis Willd. var. macropoda Fern., C. laxiflora var. serrulata, Cornus florida L., Fagus grandifolia Ehrh., Hexastylis arifolia, Liquidambar styraciflua L., Magnolia macrophylla Michx., and Polystichum acrostichoides. We have observed Carex superata growing with $C$. basiantha at six sites in Alabama and Tennessee and with $C$. willdenowii at four other localities in Kentucky, Tennessee, and Virginia (Table 5). Where syntopic with $C$. basiantha, $C$. superata usually grows intermingled with it or within a few metres of it. When growing with $C$. willdenowii, $C$. superata usually grows just downslope from the former.

Carex willdenowii inhabits dry-mesic deciduous forests that are often dominated by oaks. It grows on uplands, most often ridge tops, and high on slopes. Its substrates are acidic ( $\mathrm{pH} 4.6-5.5)$ loams and silty clay loams low in calcium and organic matter and high in iron (Table 4). It can grow in soils over calcareous rocks, but such places are leached to yield calcium-poor and acidic soils. Frequent vascular plant associates are Carex albicans Spreng. var. albicans, $C$. digitalis var. digitalis, $C$. glaucodea Tuckerm., C. hirsutella Mackenzie, C. laxiflora var. laxiflora, C. umbellata Willd., and Chimaphila maculata (L.) Pursh.

In topographic position, $\mathrm{pH}$, and water, calcium, and iron levels in the substrate, $C$. basiantha and C. willdenowii appear to represent the extremes of a continuum, with $C$. superata being intermediate. Other ecological characteristics, however (e.g., high values of soil potassium and magnesium), suggest $C$. superata is itself extreme.

Perigynia mature and are shed in $C$. basiantha from late March through early August. Carex willdenowii matures and sheds its perigynia early May-late July. Perigynium maturation and dispersal occur in $C$. superata from late March to mid-July. The asynchronously emerging spikes account for the relatively long season of perigynium production in plants of the $C$. willdenowii complex.

\section{DISCUSSION}

Three sharply distinct species exist within the $C$. willdenowii complex, although no one character distinguishes all three species. Each species has a unique set of mor-

TABLE 5. Examples of syntopy of members of the Carex willdenowii complex. Names and numbers listed are collector and number of voucher specimens. Full specimen citations are provided in the taxonomic treatment.

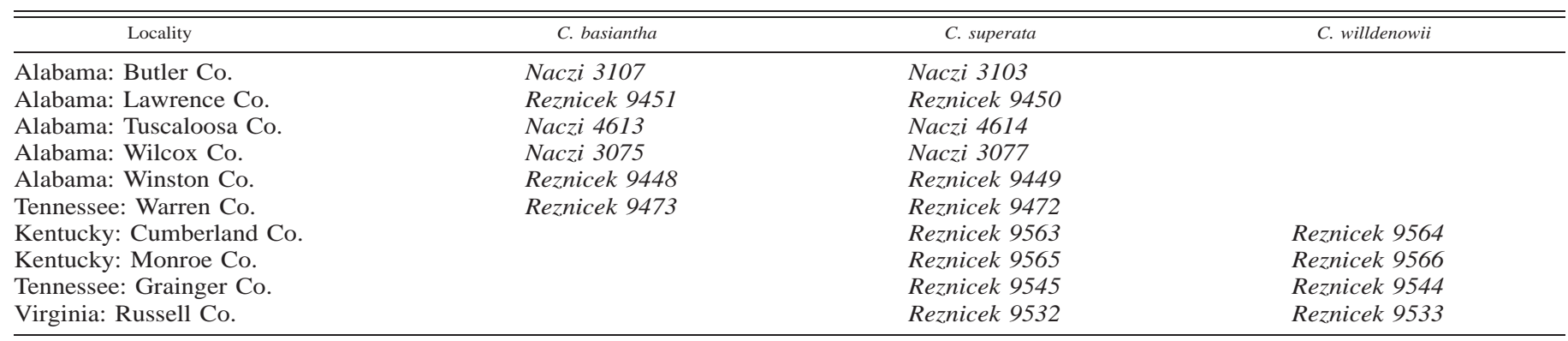


phological features, geographical affinities, and ecological requirements. Yet, the species share several features that suggest they are closely related: unusual morphological features (asynchronous spike production, perigynium bodies gradually tapering to beaks, and narrow pistillate scales), eastern North American ranges, and deciduous forest habitats.

In revealing three distinct species and identifying the most important diagnostic characters for recognizing these species, the results of ANOVA confirm the PCA results. Though the best diagnostic features are both reproductive (CLMHT, MSPL, MSCL, PERIGBKL) and vegetative (RCLM), reproductive characters dominate. Indeed, even RCLM is a combination of reproductive and vegetative features.

When Hermann (1954) described C. willdenowii var. megarrhyncha (C. superata), he noted that most specimens appeared strikingly different from $C$. willdenowii var. willdenowii, but justified his ranking of the new taxon by citing several specimens that he termed "completely transitional" between the two varieties. Hermann cited four specimens, all from Alabama, that he considered transitional: (a) Harper 3512 (Hale Co.), (b) Harper 3935 (Walker Co.), (c) Harper 3657 (Blount Co.), and (d) Svenson 10196 (Jackson Co.). These supposed intermediates are actually a mixture of $C$. basiantha and $C$. superata. As clearly indicated by their placement on the PCA plot, (b) and (d) are C. basiantha, while the other two are $C$. superata (Fig. 1). Likewise, Hermann's paratypes of $C$. willdenowii var. megarrhyncha are a mixture: (1) Harper 2131 (Houston Co., Georgia) and (6) Correll \& Correll 9557 (Iberia Parish, Louisiana) are C. basiantha, while (2) Harper 2226 (Stewart Co., Georgia), (4) Thorne 3108 et al. (Decatur Co., Georgia), and (5) Harper 3364 (Tuscaloosa Co., Alabama) are C. superata (Fig. 1). We failed to locate the third paratype (Pyron \& McVaugh 2231, Decatur Co., Georgia) and could not include the sixth paratype in the PCA because of its fragmentary nature. Apparently, Hermann's inclusion of $C$. basiantha in his concept of $C$. willdenowii var. megarrhyncha accounts for his choice of variety in erecting the new taxon.

Carex basiantha is intermediate between $C$. willdenowii and $C$. superata in only five of the 14 variables studied, including, however, the perigynium dimensions that Hermann emphasized in the diagnosis of his new variety (PERIGL, PERIGBKL). The PCA and ANOVA indicate $C$. basiantha and $C$. superata are clearly distinct. We have never found any intermediates between them. Use of characters additional to those employed by Hermann allows unequivocal separation of these species and recognition of $C$. basiantha as distinct from the two other members of the complex. Carex basiantha has the tallest culms (CLMHT), longest staminate portions of the terminal spikes (MSPL), and longest peduncles (PDCLL) of any member of the complex. Carex basiantha is not a mere "transition" between the other species, but a distinct entity that happens to have some of its characters quantitatively intermediate between those of two other species.

Each member of the $C$. willdenowii complex has a unique geographic distribution. Carex willdenowii ranges farthest north and east. Carex basiantha ranges farthest south and west. Both of these species are the only member of the complex throughout most of their ranges. Carex superata overlaps the ranges of the other species, but it is apparently the only member of the complex occurring within a portion of its range. Most of the range of each species lies in a different physiographic province, though all species do overlap in the Interior Low Plateaus of southern Tennessee and adjacent northern Alabama.

Carex willdenowii is the only species with a substantial disjunction in its range. While unusual, this disjunction is not unique. Species whose ranges include the Ouachita Mountains and areas east of the Mississippi Embayment at or near where $C$. willdenowii occurs, but not the intervening region, include Calamovilfa arcuata K. E. Rogers (Kral, 1983), Carex ouachitana Kral, Manhart, \& Bryson (McNeilus, 1992), Castanea pumila (L.) Miller var. ozarkensis (Ashe) Tucker (Johnson, 1988), Magnolia tripetala L. (Little, 1977), Monarda virgata Raf. (Scora, 1967), and Trillium pusillum Michx. var. ozarkanum (Palmer \& Steyerm.) Steyerm. (Cabe and Werth, 1995). The repeated examples of this distribution pattern suggest that the disjunction of $C$. willdenowii in the Ouachita Mountains is not due to natural long-distance dispersal nor to introduction by humans. While the population of this species in Garland County, Arkansas does occur at a recreation area, it inhabits relatively undisturbed forest there.

As with the morphological and geographical data, ecological features distinguish three species within the $C$. willdenowii complex. The members of the complex tend to grow in different habitats separated mostly by water availability, soil chemistry, and topographic position. Overlapping ranges for most of the chemistry variables as well as syntopy of pairs of species indicate that ecological separation of the species is incomplete.

For most ecological features, $C$. basiantha and $C$. willdenowii are the most divergent pair of species. This divergence probably accounts for the apparent lack of syntopy of these plants. The small size of the region of sympatry of these species also makes their co-occurrence (and of all three species) unlikely.

Carex basiantha and C. superata overlap greatly in the timing of their perigynium production and they probably overlap greatly in their flower production. Though perigynium production initiates later in $C$. willdenowii than in the other two members of the complex, the flowering period of $C$. willdenowii overlaps flowering in the others because of their asynchronous spike production. Thus, members of the complex probably have the opportunity to interbreed when syntopic. The fact that syntopic members of the complex do not hybridize or intergrade supports our contention that they are species.

The previously available names $C$. willdenowii var. megarrhyncha and $C$. willdenowii var. willdenowii imply that these taxa are more closely related to each other than either is to $C$. basiantha. This arrangement is not supported by our findings. Three independent and congruent data sets (morphology, geography, and ecology) support our hypothesis of the existence of three distinct species within the $C$. willdenowii complex. In addition, allozyme variation within the complex supports the existence of three species (Ford et al., 1998). We retain the name $C$. basiantha and, for $C$. willdenowii var. willdenowii, we 
retain the name $C$. willdenowii. Since no name is available at the rank of species for $C$. willdenowii var. megarrhyncha, we describe it below, using the epithet "superata," meaning "overtopped," in reference to one of its most distinctive features, the culms conspicuously overtopped by the leaves.

The eastern North American flora is one of the most intensively studied and best known in the world. Thus, the discovery of three species masquerading under one name is significant, though not unprecedented. Careful study of species like $C$. willdenowii s.l. has sometimes revealed them to be groups of closely related species, usually with 2-4 members. These species that turn out to be complexes are usually widespread, common, described early from northeastern North American material, of uncontroversial taxonomic status, and morphologically distinctive (often rather highly divergent from their congeners). The distinctiveness and ease of identification of these species probably lull botanists into believing these species are without taxonomic problem. Previously undetected species have become apparent especially when material from the southeast is included in taxonomic studies. Examples of recently recognized diversity include Allium burdickii (Hanes) A. G. Jones (1979) segregated from A. tricoccum Ait., Carex amplisquama F. J. Hermann (1955) segregated from C. communis L. H. Bailey, C. brysonii Naczi (1993) segregated from C. hitchcockiana Dewey, C. godfreyi Naczi (1993) segregated from C. amphibola, C. socialis Mohlenbrock and Schwegman (1969) segregated from $C$. radiata (Wahlenb.) Small, Lindera subcoriacea B. E. Wofford (1983) segregated from L. benzoin (L.) Blume, and Trillium sulcatum Patrick (1984) segregated from T. erectum L.

\section{TAXONOMIC TREATMENT}

Identification Key to Members of the Carex willdenowii Complex

Mature, complete, and ample specimens are necessary for correct identifications of the members of the Carex willdenowii complex.

1. Tallest culm $0.18-0.38$ of plant height; perigynia (7.0-) 7.5-10.8 $\mathrm{mm}$ long, with beaks (3.6-) 4.1-6.4 mm long; culms erect; peduncles usually erect to spreading ......... Carex superata

1. Tallest culm $0.41-0.87$ of plant height; perigynia $4.5-8.0 \mathrm{~mm}$ long, with beaks 1.7-4.3 mm long; culms erect to spreading; peduncles usually widely spreading to nodding

2. Longest staminate portion of terminal spikes $12.7-25.6 \mathrm{~mm}$ long; perigynia $5.8-8.0 \mathrm{~mm}$ long, with beaks $2.5-4.3 \mathrm{~mm}$ long; achenes (2.4-) 2.6-3.4 mm long . . . . . . Carex basiantha

2. Longest staminate portion of terminal spikes $4.9-8.6(-10.3) \mathrm{mm}$ long; perigynia 4.5-5.7 (-6.5) mm long, with beaks 1.7-2.6 (2.8) $\mathrm{mm}$ long; achenes $1.8-2.6 \mathrm{~mm}$ long . . . Carex willdenowii

\section{SPECIES ACCOUNTS}

Carex basiantha Steudel, Syn. Pl. Glumac. 2: 232. 1855.-TYPE: [USA. Louisiana], N.[ew] Orleans, [no date], Drummond 430 (holotype: P!, photo: KNK! $\mathrm{MICH}$ !)

Carex willdenowii var. pauciflora Olney ex E. Hall, Pl. Tex. 25. 1873., nom. nud. Carex willdenowii var. pauciflora Olney ex L.H. Bailey in J.M. Coulter, Contr. U.S. Natl. Herb. 2: 482. 1894.—TYPE:
[USA]. Texas, [Harris Co.], Houston, 20 April 1872, E. Hall 728 (holotype: GH!; isotype: $\mathrm{PH}$ !).

Perennial herb, densely caespitose. Rhizomes very short, $0.2-4 \mathrm{~mm}$ long between shoots or branches of the rhizomes, covered with cataphylls, with internodes $0.2-$ $3.5 \mathrm{~mm}$ long and $1.2-2.6 \mathrm{~mm}$ thick. Shoot bases surrounded by cataphylls, stramineous to very dark brown, sometimes chestnut. Reproductive shoots $20.7-55.3 \mathrm{~cm}$ tall, erect to spreading; culms $10.7-39.3 \mathrm{~cm}$ tall, the tallest $18.0-39.3 \mathrm{~cm}$ high, slightly to moderately overtopped by the leaves, $0.49-0.79$ of shoot height, $0.2-0.4$ $\mathrm{mm}$ wide at midheight, smooth except sparingly denticulate just basal to terminal spike, acutely trigonous and three-winged, dilated just basal to terminal spike, 0.6-1.2 $\mathrm{mm}$ wide just basal to terminal spike. Cataphylls glabrous, multicostate. Leaves $1-4$, blades $0.8-53 \mathrm{~cm}$ long, 1.4-3.7 mm wide, the widest $2.4-3.7 \mathrm{~mm}$ wide, medium green, flat to barely plicate, glabrous, margins smooth or antrorsely scaberulous in distal portion, adaxial surface smooth or sparsely antrorsely scaberulous in distal portion, abaxial surface smooth; leaf sheaths $1.6-6.3 \mathrm{~cm}$ long, tight, glabrous; adaxial face of sheaths with hyaline band, hyaline band with apex subtruncate to deeply concave; ligules lingulate, $0.5-3.2 \mathrm{~mm}$ long. Vegetative shoots $15-33 \mathrm{~cm}$ tall; leaves like those of reproductive shoots; pseudoculms $3.2-5.4 \mathrm{~cm}$ tall, $1.2-2.3 \mathrm{~mm}$ wide at mid-height, $0.11-0.22$ of shoot height. Infructescence a single terminal spike and 1-4 lateral spikes. Spikes androgynous, simple, with staminate scales and perigynia spirally and densely imbricate. Terminal spike atop widely spreading to nodding culm, 8.6-30.2 mm long, 3-7 $\mathrm{mm}$ wide; staminate portion $4.0-25.6 \mathrm{~mm}$ long, the longest $12.7-25.6 \mathrm{~mm}$ long, $0.7-1.4 \mathrm{~mm}$ wide, 4-61-flowered; pistillate portion overlapping base of staminate portion, 4-6 mm long, 3-7 mm wide, 2-4 (-6)-flowered. Lateral spikes on nodding peduncles arising from base of culm; peduncles $3.2-25.2 \mathrm{~cm}$ long, capillary, flat, narrowly two-winged, dilated just basal to spike; each spike subtended by leaf-like bracts, spikes 7.3-26 mm long, 2$7 \mathrm{~mm}$ wide; staminate portion $2.3-21.9 \mathrm{~mm}$ long, $0.4-$ $1.3 \mathrm{~mm}$ wide, 2-46-flowered; pistillate portion overlapping base of staminate portion, 3-6 $\mathrm{mm}$ long, 2-7 $\mathrm{mm}$ wide, 3-4 (-6)-flowered. Staminate scales from middle region of staminate portion of terminal spike $2.2-3.3 \mathrm{~mm}$ long, those from other parts 2.2-3.9 mm long, 1.6-2.0 $\mathrm{mm}$ wide, ovate, obtuse, center green or fading to light brown and one-nerved, margins hyaline and whitish, lateral margins free but tightly sheathing adjacent distal staminate scales. Uppermost pistillate scale of each spike $3.6-5.5 \mathrm{~mm}$ long, $1.7-2.2 \mathrm{~mm}$ wide, narrowly ovate to ovate, acute and awnless, center green and 3-5-nerved, margins hyaline, whitish with ferruginous tinge. Lowest pistillate scale of each spike 5.0-33 mm long; some like uppermost pistillate scale except longer and acuminate; others leaf-like; basal portions of leaf-like scales 0.9-2.4 mm wide, green, 4-10-nerved, partially to completely concealing perigynia; distal portions green, long-acuminate, with antrorsely scaberulous margins. Other pistillate scales morphologically intermediate between uppermost and lowest scales. Anthers 3, 0.8-1.5 mm long. Styles jointed with summits of achenes, portions distal to achenes withering with age. Stigmas 3, 2.4-2.8 $\mathrm{mm}$ long, 


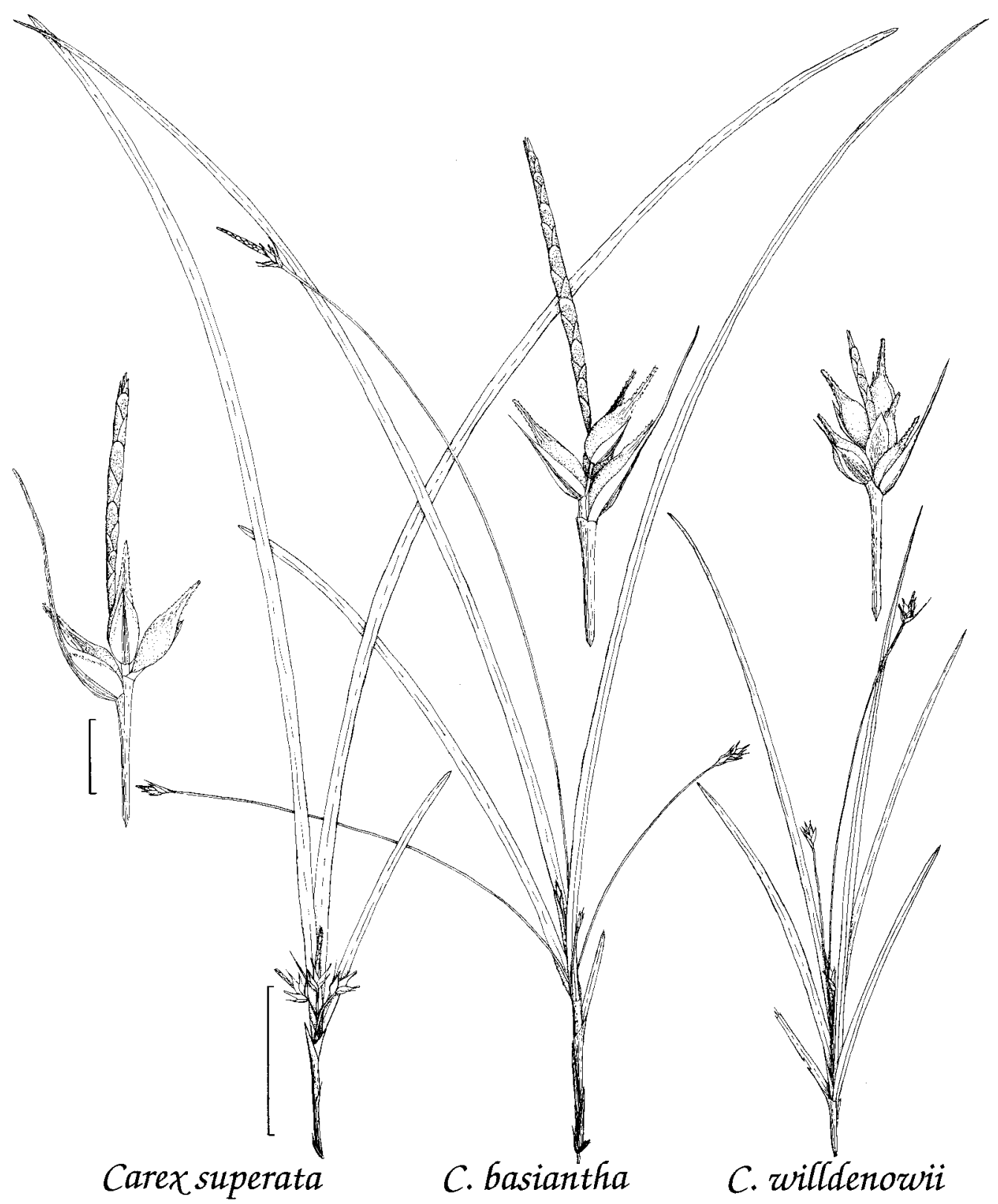

Fig. 6. Carex superata (drawn from holotype: Reznicek 9450 et al., MICH), C. basiantha (drawn from Reznicek 9448 et al., MICH), and C. willdenowii (drawn from Kriebel 1695, MICH). For each species, one typical terminal spike and one typical reproductive shoot are depicted. Bar for terminal spikes $=0.5 \mathrm{~cm}$ and bar for reproductive shoots $=4 \mathrm{~cm}$.

withering with age. Perigynia (5.8-) 6.2-7.6 (-8.0) $\mathrm{mm}$ long, $1.4-2.0 \mathrm{~mm}$ wide, (3.2-) 3.5-4.5 (-5.6) times as long as wide, (2.1-) 2.3-2.9 times as long as achenes, ascending, subterete, nerveless, glabrous, pale green to tan, often speckled with red-brown, narrowly ovoid or lance-ovoid, short-tapered from widest point to acute base, gradually and long-tapered to beak; beaks (2.5-) 2.7-3.7 (-4.3) mm long, $0.40-0.55$ of perigynium length, straight, compressed-deltoid, scaberulous on angles, apex entire. Achenes (2.4-) 2.6-3.0 (-3.4) mm long, (1.3-) $1.5-1.7(-1.9) \mathrm{mm}$ wide, tightly enveloped by perigynia, oblong, subterete to broadly trigonous in cross section, brown with three longitudinal paler brown lines that apically become low ridges intersecting at style base, basally abruptly contracted to light tan stipe, beakless; stipes $0.2-$ $0.4 \mathrm{~mm}$ long, 0.6-0.8 mm wide (Fig. 6).

Representative specimens - [Distances mentioned are as recorded on specimen labels. One $\mathrm{mi}=1.6 \mathrm{~km}$.] U.S.A. ALABAMA. Butler Co.: $\sim 0.5 \mathrm{mi} \mathrm{N}$ of Oaky Streak, 24 May 1993, Naczi 3107 (KNK*, MICH). Calhoun Co.: $14 \mathrm{mi}$ E of Gadsden, just $\mathrm{N}$ on county 19 from junction US 278, 3 Apr 1995, Kral 84412 (KNK, VDB). Colbert Co.: $\sim 10 \mathrm{mi}$ N of Russellville, 27 Mar 1972, Kral 45126 (MO, VDB). Conecuh Co.: $\sim 5$ air mi SSE of center of Evergreen, 17 May 1995, Naczi 4694 (AUA, KNK*, MICH, WIN). Crenshaw Co.: 1.9 road mi S of junction of routes $331 \& 10$ in center of Luverne, 16 May 1995, Naczi 4671 (KNK*, MICH, WIN, ctb). Hale Co.: 
vicinity of Gallion, along $\mathrm{E}$ side of route 69, 16 May 1995, Naczi 4639 (AUA, KNK*, MICH, WIN, ctb). Houston Co.: Gordon, on Chattahoochee River, 4 May 1993, MacDonald 5961 (KNK*, MICH). Jackson Co.: 1 mi W of Scottsboro, 3 May 1939, Svenson 10196 (MO, NA*, PH, US, VDB). Lawrence Co.: Borden Creek, Bankhead National Forest, 15 May 1992, Bryson 11633 (KNK*, ctb); $\sim 11.5$ mi N of Double Springs, Bankhead National Forest, 25 May 1993, Reznicek 9451 et al. (KNK, MICH). Marshall Co.: 6 mi E of Guntersville,

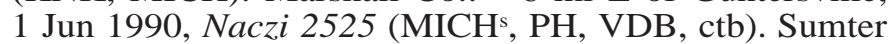
Co.: $\sim 1$ mi E of Parker siding, 4 May 1935, Harper 3362 (MO, US). Tuscaloosa Co.: on Warrior River near Lock 14, 4 Apr 1933, Harper 3033 (MO, PH); near Warrior River, 4 Apr 1952, Harper 4240 (MO); 8 air mi NE of center of Tuscaloosa, at Black Warrior River, 15 May 1995, Naczi 4613 (KNK*, MICH, WIN). Walker Co.: $\sim 2.5 \mathrm{mi} \mathrm{S}$ of Jasper, in ravine $\mathrm{S}$ of Cane Creek, $30 \mathrm{Apr}$ 1943, Harper 3935 (MO, PH, US*). Wilcox Co.: $0.8 \mathrm{mi}$ N of Oak Hill, 23 May 1993, Naczi 3075 (KNK* ${ }^{*}$ MICH, WIN); 2 mi S of Ackerville, 23 May 1993, Naczi 3086 $\left(\mathrm{KNK}^{* \mathrm{~s}}\right)$. Winston Co.: $\sim 9.5 \mathrm{mi} \mathrm{N}$ of Double Springs, Bankhead National Forest, 25 May 1993, Reznicek 9448 et al. (KNK*, MICH).-ARKANSAS. Drew Co.: 3-5 mi NW of Monticello at Hunger Run Creek, 17 Jun 1992, Sundell 10282 \& Godwin (VDB). Ouachita Co.: $\sim 5 \mathrm{mi}$ N of Lester, 23 Apr 1987, Orzell \& Bridges 5141 $\left(\mathrm{MICH}^{*}\right)$. Scott Co.: $2 \mathrm{mi}$ N of Y City, 10 May 1989, Naczi 2127 (MICH', UARK, ctb); 20 May 1994, Naczi 3938 \& Ford (KNK*, MICH, WIN). Sevier Co.: $8 \mathrm{mi} \mathrm{E}$ of DeQueen, 10 May 1989, Naczi 2121 (MICH, UARK, VDB, ctb).-FLORIDA. Alachua Co.: vicinity of Gainesville, Devils Mill Hopper, 3 Aug 1926, Crawford s.n. (PH). Bay Co.: $1 \mathrm{mi} \mathrm{N}$ of Bennett, above Mocassin Creek, 9 Apr 1966, McDaniel 7367 (IBE, VDB). Gadsden Co.: Aspalaga, Apr 1898, Chapman s.n. (MO). Hamilton Co.: W of Jasper, S of Alapaha River by I-75, 13 Mar 1976, Kral 57226 (VDB). Jackson Co.: Marianna Caverns State Park, 7 Apr 1961, Mitchell 978 (US). Leon Co.: 2 mi ESE of Tallahassee, 26 Apr 1925, Harper 31 (PH, US). Levy Co.: 15 mi E of Cedar Key, 17 Mar 1976, Kral 57322 (VDB).-GEORGIA. Dougherty Co.: $\sim 9 \mathrm{mi}$ W of Albany, 8 Apr 1977, Kral 59558 (VDB). Early Co.: $\sim 1.5 \mathrm{mi}$ NW of Hilton, along Chattahoochee River, 18 May 1995, Naczi 4714 (GA, KNK*, MICH, WIN). Houston Co.: $\sim 2$ mi S of Elko, 16 Apr 1904, Harper 2131 (MO, US*).-LOUISIANA. Grant Parish: Packton, 19 May 1995, Hyatt 6433 (MICH*). Iberia Parish: Avery Island, 11-15 Jul 1938, Correll \& Correll 9557 (NA). West Feliciana Parish: along W side of route 61, just S of St. Francis Hotel, 23 May 1994, Naczi 3987 \& Ford (KNK*, MICH, WIN).-MISSISSIPPI. Carroll Co.: $\sim 2.2$ mi W of Carrollton, 22 Apr 1987, Bryson 5407 (MICH, MO). Holmes Co.: 6.2 mi E of Thornton, 14 Apr 1992, Bryson 11221 \& Newton (KNK*, ctb). Itawamba Co.: 9 mi N of Mantachie, 25 May 1994, Naczi 4005 \& Bryson (KNK*, WIN). Lee Co.: W of Tupelo, $1 \mathrm{mi} \mathrm{E}$ of LeePontotoc Co. line, 17 Apr 1992, Bryson 11332 (KNK*, ctb). Oktibbeha Co.: $1 \mathrm{mi} \mathrm{N}$ of Starkville, 25 Apr 1982, Bryson 3217 (MICH*, ctb). Wilkinson Co.: $1.2 \mathrm{mi} \mathrm{W}$ of Lessley, 11 May 1990, Naczi 2390 (MICH', VDB, ctb).-NORTH CAROLINA. Pender Co.: $\sim 2 \mathrm{mi} \mathrm{E}$ of Rocky Point, N of NC 210, McRae Farm, 12 May 1971,
Leonard 4767 (NA).-OKLAHOMA. McCurtain Co.: $\sim 4 \mathrm{mi} \mathrm{N}$ of Idabel, 21 May 1994, Naczi 3954 \& Ford (KNK*, MICH, WIN).-SOUTH CAROLINA. Dorchester Co.: Givhans Ferry State Park, E bank of Edisto River, N of route 61, 15 May 1988, Hill 19357 \& Soblo (KNK*, MICH, MO, USCH, srh).-TENNESSEE. Franklin Co.: Bean's Creek, 4 May 1939, Svenson 9986 (US). Grundy Co.: $10.9 \mathrm{mi} \mathrm{SW}$ of Altamont, 27 May 1993, Reznicek 9469 \& Naczi (KNK*, MICH). Maury Co.: by I-65, $4.7 \mathrm{mi} \mathrm{N}$ of Tenn. 99, 13 Apr 1973, Kral 49539 (MO, VDB). Shelby Co.: $\sim 6$ air mi SW of Memphis, 26 Jun 1995, Naczi 4814 \& Reznicek (KNK*, MICH); 14 air mi N of Memphis, Meeman-Shelby Forest State Park, 26 Jun 1995, Naczi 4825 \& Reznicek (KNK* ${ }^{*}$ MICH, VDB, WIN). Tipton Co.: $\sim 2.5$ air mi NW of Gilt Edge, just S of Hatchie River, 27 Jun 1995, Naczi 4829 \& Reznicek (KNK*, MICH). Warren Co.: Rock Island State Park, along Rocky River, 27 May 1993, Reznicek 9473 et al. (KNK*, MICH). Weakley Co.: 3.5 air mi SE of Greenfield, along W side of McAdams Road, 28 Jun 1995, Naczi 4861 \& Reznicek (KNK*, MICH, TENN, US, VDB, WIN, ctb).-TEXAS. Jasper Co.: $\sim 12$ mi W of Jasper, 22 May 1994, Naczi 3965 \& Ford (KNK*, WIN). Montgomery Co.: $\sim 3 \mathrm{mi} \mathrm{W}$ of Conroe, 3 Apr 1989, Orzell \& Bridges 8893 (MICH*). Polk Co.: $\sim 5 \mathrm{mi} \mathrm{W}$ of Livingston, 10 Apr 1989, Orzell \& Bridges 9116 (MICH*). Wharton Co.: Wharton, 18 Mar 1914, Palmer 4980 (CU, US).

Carex superata Naczi, Reznicek, \& B.A. Ford, sp. nov.TYPE: U.S.A. Alabama: Lawrence Co., $\sim 11.5 \mathrm{mi} \mathrm{N}$ of Double Springs, Bankhead National Forest, S bank of Borden Creek just W of gate on Forest Road 224, NE1/4 sect. 32, T8S, R8W, 25 May 1993, Reznicek 9450, Reznicek, Bryson, Naczi, Huntley, \& Oberholster (holotype: MICH!; isotypes: KNK*! MO! NY! UNA! US! VDB! WIN! ctb!).

Carex willdenowii var. megarrhyncha F.J. Hermann, Amer. Midl. Naturalist 51: 277. 1954.-TYPE: [USA]. Georgia: Jasper Co., $3.5 \mathrm{mi}$ E of Ocmulgee, open woods along small stream, 6 April 1949, S.J. Smith \& W.H. Duncan 4872 (holotype: US*!)

Herba perennis, dense caespitosa. Rhizomata brevia, 0.2-1 mm longa inter surculos vel ramos rhizomatum; internodiis $0.2-1 \mathrm{~mm}$ longis, $1.2-1.8 \mathrm{~mm}$ crassis. Bases surculorum stramineae vel fuligineae. Surculi reproductivi 17.1-64.6 cm alti; culmi $4.7-14.4 \mathrm{~cm}$ alti, $0.4-0.8$ $\mathrm{mm}$ lati ad altitudinem mediam, laeves, foliis magnopere superati, altitudine $0.18-0.38$ surculorum aequantes. Folia 1-4; laminae glabrae, 1.6-61 cm longae, 1.2-4.6 mm latae, lamina latissima $2.7-4.6 \mathrm{~mm}$ lata; vaginae glabrae, arctae; ligulae truncatae. Surculi vegetativi nulli. Infructescentiae ex spica terminali unica et ex $0-2(-3)$ spicis lateralibus constructae. Spicae androgynae. Spica terminalis erecta, 7.7-23 mm longa, 3-9 mm lata; pars staminata longissima 9.6-20.1 mm longa, 7-56 floribus instructa; pars pistillata 2-4 (-6) floribus instructa. Spicae laterales erectae vel patentes (raro cernuae), in pedunculis capillaceis $2.5-11.3 \mathrm{~cm}$ longis ex basibus culmorum portatae, 8.7-13 mm longis, 4-7 mm latis; partes staminatae 2.2-8.4 mm longis, 2-6 floribus instructae; partes pistillatae 2-6 floribus instructae. Squamae staminatae ex parte mediana partis staminatae spicae terminalis 2.5-3.4 
mm longae, 1.6-2.0 mm latae. Squamae pistillatae 4.0$43 \mathrm{~mm}$ longae, 0.9-2.4 mm latae. Perigynia (7.0-) 7.58.9 (-10.8) mm longa, 1.5-2.3 mm lata, (3.5-) 4.0-5.2 (-5.9)plo longiora quam latiora, acheniis (2.1-) 2.32.9plo longiora, ascendentia, subteretia, enervia, glabra, anguste ovoidea vel lanciovoidea, in basim acutam abrupte contracta, in rostrum gradatim contracta; rostra (3.6-) 4.1-5.0 (-6.4) mm longa, longitudine 0.51-0.63 perigyniorum aequantia, recta, compressideltoidea, apicibus integris. Achenia (2.1-) 2.5-3.1 (-3.3) mm longa, (1.4-) 1.5-1.9 (-2.1) mm lata, oblonga, subteretia, perigyniis arcte inclusa, in stipitem abrupte contracta; stipites $0.3-$ $0.5 \mathrm{~mm}$ longi, $0.6-1.1 \mathrm{~mm}$ lati.

Perennial herb, densely caespitose. Rhizomes very short, 0.2-1 mm long between shoots or branches of the rhizomes, covered with cataphylls, with internodes $0.2-$ $1 \mathrm{~mm}$ long and 1.2-1.8 mm thick. Shoot bases surrounded by cataphylls, stramineous to very dark brown. Reproductive shoots $17.1-64.6 \mathrm{~cm}$ tall, erect to spreading; culms $4.7-14.4 \mathrm{~cm}$ tall, the tallest $7.1-14.4 \mathrm{~cm}$ high, greatly overtopped by the leaves, $0.18-0.38$ of shoot height, $0.4-0.8 \mathrm{~mm}$ wide at midheight, smooth throughout, acutely trigonous and three-winged, dilated just basal to terminal spike, $0.5-1.4 \mathrm{~mm}$ wide just basal to terminal spike. Cataphylls glabrous, multicostate. Leaves 1-4, blades $1.6-61 \mathrm{~cm}$ long, $1.2-4.6 \mathrm{~mm}$ wide, the widest 2.7-4.6 mm wide, deep green, flat to barely plicate, glabrous, margins smooth or antrorsely scaberulous in distal portion, adaxial surface smooth or sparsely antrorsely scaberulous in distal portion, abaxial surface smooth; leaf sheaths 1.6-8.4 cm long, tight, glabrous; adaxial face of sheaths with hyaline band, hyaline band with apex truncate; ligules truncate. Vegetative shoots lacking. Infructescence a single terminal spike and $0-2(-3)$ lateral spikes. Spikes androgynous, simple, with staminate scales and perigynia spirally and densely imbricate. Terminal spike atop erect culm, 7.7-23 mm long, 3-9 mm wide; staminate portion $5.4-20.1 \mathrm{~mm}$ long, the longest 9.6-20.1 mm long, 0.7-1.6 mm wide, 7-56-flowered; pistillate portion overlapping base of staminate portion, 8$13 \mathrm{~mm}$ long, 3-9 mm wide, 2-4 (-6)-flowered. Lateral spikes usually on erect or spreading (rarely drooping) peduncles arising from base of culm; peduncles 2.5-11.3 $\mathrm{cm}$ long, capillary, flat, narrowly two-winged, dilated just basal to spike; each spike subtended by leaf-like bracts, spikes $8.7-13 \mathrm{~mm}$ long, 4-7 $\mathrm{mm}$ wide; staminate portion 2.2-8.4 mm long, 0.3-0.9 mm wide, 2-6-flowered; pistillate portion overlapping base of staminate portion, 8$13 \mathrm{~mm}$ long, 4-7 mm wide, 2-6-flowered. Staminate scales from middle region of staminate portion of terminal spike 2.5-3.4 mm long, those from other parts 2.5$4.1 \mathrm{~mm}$ long, 1.6-2.0 mm wide, ovate, obtuse, center green or fading to light brown and one-nerved, margins hyaline and whitish, lateral margins free but tightly sheathing adjacent distal staminate scales. Uppermost pistillate scale of each spike 4.0-9.2 mm long, 1.3-2.2 mm wide; body $3.4-4.6 \mathrm{~mm}$ long, narrowly ovate, acute and awnless or with midrib prolonged as antrorsely scaberulous awn 0.5-5.7 $\mathrm{mm}$ long, center green and 3-5nerved, margins hyaline, whitish with ferruginous tinge. Lowest pistillate scale of each spike 4.0-43 mm long; some like uppermost pistillate scale except with awn 2$17 \mathrm{~mm}$ long; others leaf-like; basal portions of leaf-like scales 0.9-2.4 mm wide, white, 4-9-nerved, usually only partially concealing perigynia but sometimes completely concealing them; distal portions green, long-acuminate, with antrorsely scaberulous margins. Other pistillate scales morphologically intermediate between uppermost and lowest scales. Anthers 3, 1.1-1.4 mm long. Styles jointed with summits of achenes, portions distal to achenes withering with age. Stigmas 3, 2.2-2.9 mm long, withering with age. Perigynia (7.0-) 7.5-8.9 (-10.8) $\mathrm{mm}$ long, 1.5-2.3 mm wide, (3.5-) 4.0-5.2 (-5.9) times as long as wide, (2.6-) 2.7-3.1 (-3.5) times as long as achenes, ascending, subterete, nerveless, glabrous, pale green to tan, often speckled with red-brown, narrowly ovoid or lance-ovoid, short-tapered from widest point to acute base, gradually and long-tapered to beak; beaks (3.6-) 4.1-5.0 (-6.4) mm long, 0.51-0.63 of perigynium length, straight, compressed-deltoid, scaberulous on angles, apex entire. Achenes (2.1-) 2.5-3.1 (-3.3) $\mathrm{mm}$ long, (1.4-) 1.5-1.9 (-2.1) mm wide, tightly enveloped by perigynia, oblong, subterete, brown with three longitudinal paler brown lines that apically become low ridges intersecting at style base, basally abruptly contracted to light tan stipe, beakless; stipes $0.3-0.5 \mathrm{~mm}$ long, 0.6-1.1 mm wide (Fig. 6).

Representative specimens-[Distances mentioned are as recorded on specimen labels. One $\mathrm{mi}=1.6 \mathrm{~km}$.]U.S.A. ALABAMA. Blount Co.: NW base of Warnock Mountain, 4 May 1938, Harper 3657 (MO, US*). Butler Co.: $\sim 0.5 \mathrm{mi} \mathrm{N}$ of Oaky Streak, 24 May 1993, Naczi 3103 (KNK*s, MICH, US, WIN, ctb); Greenville, $3 \mathrm{mi} \mathrm{N}$ of center of town along route 263, 24 May 1994, Naczi 3993 \& Ford (KNK*, MICH, WIN). Hale Co.: $\sim 0.5 \mathrm{mi}$ $\mathrm{N}$ of Havana, 22 May 1936, Harper 3512 (MO, US*). Madison Co.: Huntsville, Monte Sano State Park, 6 May 1991, Naczi 2880 (MICH*). Monroe Co.: N of Midway, 28 Apr 1991, Naczi 2815 (KNK*s, MICH, VDB); $2 \mathrm{mi}$ NNE of Tunnel Springs, 23 May 1993, Naczi 3071 $\left(\mathrm{KNK}^{*}, \mathrm{MICH}\right)$; $\sim 3 \mathrm{mi}$ W of Midway, 23 May 1993, Naczi 3073 (AUA, KNK*, MICH, WIN, ctb). Tuscaloosa Co.: $\sim 1 \mathrm{mi} \mathrm{S}$ of Peterson, tributary to Hurricane Creek, 9 May 1935, Harper 3364 (MO, NY, US ${ }^{*}$ ); $\sim 8$ air mi NE of center of Tuscaloosa, at Black Warrior River, 15 May 1995, Naczi 4614 (KNK*', MICH, WIN, ctb). Wilcox Co.: $0.8 \mathrm{mi}$ N of Oak Hill, 23 May 1993, Naczi 3077 (KNK* $\left.{ }^{*}, \mathrm{MICH}\right)$. Winston Co.: $\sim 9.5 \mathrm{mi} \mathrm{N}$ of Double Springs, Bankhead National Forest, 25 May 1993, Reznicek 9449 et al. (KNK*, MICH); $8.5 \mathrm{mi} \mathrm{NNW}$ of Double Springs, Bankhead National Forest, 26 May 1993, Reznicek 9459 et al. (KNK*, MICH).-FLORIDA. Gadsden Co.: Chattahoochee Nature Park, 27 May 1984, Saucier s.n. (MICH*, VDB).-GEORGIA. Decatur Co.: $1 \mathrm{mi}$ N of Chattahoochee, along Flint River, 14 Apr 1947 , Thorne 3108 et al. (US*). Randolph Co.: $\sim 3.5 \mathrm{mi} \mathrm{W}$ of Cuthbert, 16 Jul 1903, Harper 1879 (MO, US). Stephens Co.: N of Toccoa, S side of Panther Creek, 25 Jun 1975, Boufford 16787 \& Wood (CM). Stewart Co.: 2 mi NW of Lumpkin, 25 May 1904, Harper 2226 (MO, US*). Upson Co.: $\sim 4$ mi SW of Thomaston, by GA 36, $12 \mathrm{Apr}$ 1976, Kral 57675 (KNK, VDB).-KENTUCKY. Cumberland Co.: N side of Kentucky Hwy. 214, 2.2 mi W of junction with Hwy. 61 at Peytonsburg, 23 Jun 1993, Reznicek 9563 et al. (KNK*, MICH). Monroe Co.: $\sim 12 \mathrm{mi}$ ESE of Tompkinsville, 23 Jun 1993, Reznicek 9565 et al. 
(KNK*, MICH). Todd Co.: 3 mi E of Kirkmansville, 26 May 1970, Conrad 1006 (MO).-MISSISSIPPI. Tishomingo Co.: $\sim 10 \mathrm{mi}$ N of Iuka, J.P. Coleman State Park, 25 May 1994, Naczi 4013 et al. (KNK*, WIN).-SOUTH CAROLINA. Abbeville Co.: Johns Creek, 21 Jun 1992, Hill 23444 \& Wilson (MICH*, USCH). Aiken Co.: NW of North Augusta, junction of Fox and Pole Creeks on SC 230, 9 Jun 1962, Ahles 56855 \& Baird (NCU). Edgefield Co.: Lick Fork Recreation Area, Sumter National Forest, 30 May 1993, Hill 25079 \& Dorsey (srh*). Fairfield Co.: near Mayo Creek, N of SC 16, 22 Jun 1983, Nelson 8331 (USCH). Lancaster Co.: $\sim 3$ mi S of Taxahaw, Flat Creek on U.S. 601, 26 Apr 1959, Ahles 52677 (NCU, VDB). McCormick Co.: Sumter National Forest, near Byrd Creek, E of county route 21, 15 Apr 1993, Hill 24863 (USCH).-TENNESSEE. Dickson Co.: $2.8 \mathrm{mi} \mathrm{W}$ of White Bluff, 3 May 1975, Kral 55385 (MICH*, VDB). Franklin Co.: end of Jackson County (Alabama) route 56, 2 May 1971, Kral 42454b (MICH*, MO, VDB). Grainger Co.: $\sim 5 \mathrm{mi} \mathrm{NE}$ of Thorn Hill, 22 Jun 1993, Reznicek 9545 et al. (KNK*, MICH). Overton Co.: 12.2 mi NW of Wilder, by TN 85, 20 May 1971, Kral 42719 (VDB). Warren Co.: Rock Island State Park, along Rocky River, 27 May 1993, Reznicek 9472 et al. (KNK*, MICH).VIRGINIA. Russell Co.: NE of Lebanon, Pucketts Hole, W side of route 652 at Clinch River crossing, 21 Jun 1993, Naczi 3156 \& Reznicek (KNK ${ }^{*}$ ); slopes of Clinch River at river mile 290.5, 21 Jun 1993, Reznicek 9532 et al. $\left(\mathrm{KNK}^{*}, \mathrm{MICH}\right)$.

Carex willdenowii Willdenow, Sp. P1. 4: 211. 1805.TYPE: America Boreali, [no date], Mühlenberg s.n. (holotype: B-W no. 17112b!, microfiche: MICH!).

Perennial herb, densely caespitose. Rhizomes very short, $0.2-2.8 \mathrm{~mm}$ long between shoots or branches of the rhizomes, covered with cataphylls, with internodes $0.2-1.7 \mathrm{~mm}$ long and $1.2-1.8 \mathrm{~mm}$ thick. Shoot bases surrounded by cataphylls, stramineous to medium brown, usually tan. Reproductive shoots $6.9-64.2 \mathrm{~cm}$ tall, erect to spreading; culms $3.1-29.7 \mathrm{~cm}$ tall, the tallest 8.2-29.7 $\mathrm{cm}$ high, slightly to moderately overtopped by the leaves, $0.41-0.87$ of shoot height, $0.4-0.9 \mathrm{~mm}$ wide at midheight, smooth except sparingly denticulate just basal to terminal spike, acutely trigonous and three-winged, dilated just basal to terminal spike, $0.6-1.0 \mathrm{~mm}$ wide just basal to terminal spike. Cataphylls glabrous, multicostate. Leaves 2-7, blades 5.1-58 cm long, 1.3-3.2 mm wide, the widest $2.0-3.2 \mathrm{~mm}$ wide, medium green, flat to barely plicate, glabrous, margins smooth or antrorsely scaberulous in distal portion, adaxial surface often minutely papillate, otherwise smooth or sparsely antrorsely scaberulous in distal portion, abaxial surface smooth; leaf sheaths $0.5-5.6 \mathrm{~cm}$ long, tight, glabrous; adaxial face of sheaths with hyaline band, hyaline band with apex subtruncate to slightly concave; ligules subtruncate to depressed-lingulate, 0.2-0.9 $\mathrm{mm}$ long. Vegetative shoots 11-39 cm tall; leaves like those of reproductive shoots; pseudoculms $1.4-5.5 \mathrm{~cm}$ tall, $1.4-2.1 \mathrm{~mm}$ wide at midheight, $0.13-0.18$ of shoot height. Infructescence a single terminal spike and (0-) 2-4 lateral spikes. Spikes androgynous, simple, with staminate scales and perigynia spirally and densely imbricate. Terminal spike atop widely spreading to nodding culm, 6.6-17.1 mm long, 3-7 mm wide; staminate portion $3.4-10.3 \mathrm{~mm}$ long, the longest 4.9-8.6 (-10.3) mm long, 0.7-1.4 mm wide, 3-29flowered; pistillate portion overlapping base of staminate portion, 4-14 $\mathrm{mm}$ long, 3-7 mm wide, 3-8 (-9)-flowered. Lateral spikes on widely spreading to nodding peduncles arising from base of culm; peduncles 2.8-22.1 $\mathrm{cm}$ long, capillary, flat, narrowly two-winged, dilated just basal to spike; each spike subtended by leaf-like bracts, spikes $6.9-10.6 \mathrm{~mm}$ long, 3-7 mm wide; staminate portion 1.7-5.7 mm long, 0.6-1.3 mm wide, 2-6-flowered; pistillate portion overlapping base of staminate portion, 7-11 mm long, 3-7 mm wide, 3-8-flowered. Staminate scales from middle region of staminate portion of terminal spike 1.7-2.6 mm long, those from other parts $1.4-$ $2.8 \mathrm{~mm}$ long, 1.8-2.2 mm wide, ovate, obtuse, center green or fading to light brown and one-nerved, margins hyaline and whitish, lateral margins free but tightly sheathing adjacent distal staminate scales. Uppermost pistillate scale of each spike $2.7-4.1 \mathrm{~mm}$ long, 1.5-1.9 mm wide, ovate, acute and awnless, center green and 3 5-nerved, margins hyaline, whitish with ferruginous tinge. Lowest pistillate scale of each spike $3.8-48 \mathrm{~mm}$ long; some like uppermost pistillate scale except longer and with awn 0.3-26 mm long; others leaf-like; basal portions of leaf-like scales 1.6-2.2 mm wide, green, 47-nerved, partially concealing perigynia; distal portions green, long-acuminate, with antrorsely scaberulous margins. Other pistillate scales morphologically intermediate between uppermost and lowest scales. Anthers 3, 0.9$1.1 \mathrm{~mm}$ long. Styles jointed with summits of achenes, portions distal to achenes withering with age. Stigmas 3, 1.6-2.2 $\mathrm{mm}$ long, withering with age. Perigynia (4.5-) 4.9-5.7 (-6.5) $\mathrm{mm}$ long, $1.3-1.7 \mathrm{~mm}$ wide, (2.6-) 3.1$3.9(-4.4)$ times as long as wide, (2.1-) 2.3-2.5 (-2.8) times as long as achenes, ascending, subelliptic to broadly trigonous in cross section, nerveless, glabrous, pale green to tan, narrowly ovoid or lance-ovoid, short-tapered from widest point to acute base, gradually and long-tapered to beak; beaks (1.7-) 1.9-2.6 (-2.8) $\mathrm{mm}$ long, $0.38-0.47$ of perigynium length, straight, compresseddeltoid, scaberulous on angles, apex entire. Achenes (1.8-) 2.1-2.5 (-2.6) mm long, (1.2-) 1.3-1.5 (-1.6) $\mathrm{mm}$ wide, tightly enveloped by perigynia, oblong, broadly trigonous, brown with three longitudinal paler brown lines that apically become low ridges intersecting at style base, basally abruptly contracted to light tan stipe, beakless; stipes 0.2-0.4 mm long, 0.6-0.8 mm wide (Fig. 6).

Representative specimens-[Distances mentioned are as recorded on specimen labels. One $\mathrm{mi}=1.6 \mathrm{~km}$.] CANADA. ONTARIO. Haldimand-Norfolk Regional Municipality: $3.2 \mathrm{~km}$ NNE of Canborough, 16 Jun 1986, Gartshore 86-247 $\left(\mathrm{MICH}^{*}\right)$. Niagara Regional Municipality: near Niagara, 28 Jun 1892, Macoun s.n. (US).U.S.A. ALABAMA. Lawrence Co.: Kinlock Falls, Bankhead National Forest, 1 Jun 1978, Bryson 2086 (VDB, ctb). ARKANSAS. Garland Co.: $\sim 17$ air mi $\mathrm{N}$ of Hot Springs, Iron Springs Recreation Area of Ouachita National Forest, 24 May 1987, Bryson 5752 (MICH, MO, VDB, ctb); 19 May 1994, Naczi 3924 \& Ford (KNK*, WIN).-CONNECTICUT. New Haven Co.: East Haven, 29 May 1890, Harger s.n. (NEBC).-DELAWARE. New Castle Co.: near Centreville, 7 Jun 1867, Commons s.n. (PH, US).-ILLINOIS. Pope Co.: Lusk Creek, S of Little 
Bear Branch and N of Bear Branch, 23 May 1988, Phillippe 13203 (ILLS). Union Co.: along Bald Knob Cross Road, 26 May 1988, Phillippe 13263 (ILLS).--INDIANA. Dubois Co.: 2 mi N of Huntingburg, 18 May 1918, Deam 24896 (MO, US). Harrison Co.: mi 98 of I-64 W, 22 May 1988, Brant 1790 (MO). Henry Co.: $2.5 \mathrm{mi} \mathrm{NE}$ of Mount Summit, 7 Jun 1938, Kriebel 5338 (NA). Lawrence Co.: $1.5 \mathrm{mi}$ SW of Heltonville, 23 May 1934, Kriebel 1695 (MICH). Parke Co.: Turkey Run State Park, 11 May 1957, Starcs 1540 (US). Posey Co.: 3 mi S of New Harmony, 4 Jun 1934, Hermann 6131 (MICH $\left.{ }^{*}\right)$.- KENTUCKY. Bath Co.: $\sim 5$ air mi ESE of Owingsville, 16 May 1994, Naczi 3893 (KNK*). Boyle Co.: Central Kentucky Wildlife Refuge, 13 May 1992, McKinney 4989 \& Gladu (KNK*). Campbell Co.: $\sim 4.5 \mathrm{mi}$ SE of Alexandria, along Wagner Road, 7 Jun 1980, Buddell 165 \& Thieret $\left(\mathrm{KNK}^{*}\right) ; 1.6 \mathrm{mi} \mathrm{E}$ of Persimmon Grove, 10 May 1994, Naczi 3831 (KNK $^{\mathrm{s}}$ ); $\sim 1.5$ air mi W of California, along S side of California Cross Road, 11 Jun 1994, Naczi 4087 (KNK*). Clay Co.: just E of Bush, $\sim 4.5 \mathrm{mi} \mathrm{W}$ of Hima, 28 May 1993, Reznicek 9478 \& Naczi (KNK*, MICH). Cumberland Co.: S side of Kentucky Hwy. 214, $0.6 \mathrm{mi}$ W of junction with Hwy. 61 at Peytonsburg, 23 Jun 1993, Reznicek 9562 et al. (KNK* $\left.{ }^{*} \mathrm{MICH}\right)$; N side of Kentucky Hwy. 214, 2.2 mi W of junction with Hwy. 61 at Peytonsburg, 23 Jun 1993, Reznicek 9564 et al. (KNK, MICH). Franklin Co.: $\sim 6.5$ air mi NW of Frankfort, 11 May 1994, Naczi 3835 \& Borne (KNK*). Graves Co.: NE of Mayfield, 3 May 1990, McKinney 4178 (VDB). Hart Co.: 9 mi NW of Horse Cave, 26 Jul 1994, Naczi 4483 \& Flynn (KNK). Lawrence Co.: NE of Fallsburg, 24 May 1993, Cusick 30717 (MICH). Lewis Co.: $\sim 1$ mi SE of Vanceburg along $\mathrm{N}$ side of route 546, 16 May 1994, Naczi $3888\left(\mathrm{KNK}^{*}\right)$. Monroe Co.: $\sim 12 \mathrm{mi}$ ESE of Tompkinsville, 23 Jun 1993, Reznicek 9566 et al. (KNK*, MICH). Nelson Co.: New Hope, 5 Jun 1934, Sister Rose Agnes 1381 (US). Pendleton Co.: 3.5 air mi NE of Falmouth, Kincaid Lake State Park, 3 Jun 1994, Naczi 4062 \& Thieret (KNK*, MICH). Pulaski Co.: S side Hwy. 80, 0.4 mi W of the Rockcastle River bridge, 23 Jun 1993, Reznicek 9570 et al. (KNK*, MICH). Rockcastle Co.: 1.8 mi NE of Disputanta, 14 Jun 1989, Denton 378 et al. (BEREA). Wayne Co.: N bank of Otter Creek, $\sim 0.25 \mathrm{mi} \mathrm{N}$ of Hwy. 90 bridge, 23 Jun 1993, Reznicek 9568 et al. (KNK*, MICH). Whitley Co.: $\sim 8 \mathrm{mi} \mathrm{E}$ of Williamsburg, 29 May 1993, Naczi 3153 (KNK*, MICH, US, WIN, ctb).-MARYLAND. Cecil Co.: 0.8 mi NNW of North East, 13 Jun 1990, Naczi 2575 (MICHs, PH). Garrett Co.: Jennings, 25 Jun 1907, Stone 8564 (PH).MASSACHUSETTS. Middlesex Co.: Malden, 6 Jun 1863, Boott s.n. (US). Norfolk Co.: Randolph, Ponkapog, 26 Jun 1897, Churchill s.n. (MO, NEBC).-NEW JERSEY. Hunterdon Co.: $1 \mathrm{mi}$ SW of Linvale, 13 Jun 1936, Benner 7183 (PH). Mercer Co.: $1 \mathrm{mi} \mathrm{S}$ of Harbourton, 13 Jun 1936, Long 48745 (PH). Middlesex Co.: Bonhamtown, 18 May 1919, Mackenzie s.n. (PH). Ocean Co.: Toms River, 4 Jun 1927, Crawford s.n. (PH).-NEW YORK. Bronx Co.: Bronx Park, 23 May 1897, Bicknell 3354 (PH). Cayuga Co.: N of Moravia, 14 Jun 1897, Atwood s.n. (PH). Dutchess Co.: vicinity of Pine Plains, 28 Jun 1878, Hoysradt s.n. (MICH $\left.{ }^{*}\right)$. Livingston Co.: Letchworth State Park, 22 Jun 1985, Rettig 1356 $\left(\mathrm{MICH}^{*}\right)$. Tompkins Co.: Ithaca, Cascadilla Creek, 26 Jun
1881, Curtice s.n. (MO).-NORTH CAROLINA. Caswell Co.: 2 mi SE of Hightowers, Lynch Creek, 4 Jun 1960, Radford 43282 (NCU). Chatham Co.: along Fox Creek near Mt. Carmel Church-Farrington Road, 7 May 1949, Radford 4062 (NCU). Dare Co.: Nags Head, Apr 1898, Ashe s.n. (NCU). Graham Co.: $0.2 \mathrm{mi} \mathrm{W}$ of Graham-Swain Co. line, NE of Round Top Mt., 29 May 1956, Radford 11804 (NCU). Granville Co.: 1.5 mi SSE of Stem, near Ledge Creek, 16 Jun 1961, Radford 43936 (NCU). Montgomery Co.: Uwharrie National Forest, along W Fork of McLean Creek, Parks' Place Road, 18 May 1970, Leonard 3200 et al. (AUA, NCU, PAC). Moore Co.: $2.5 \mathrm{mi}$ SE of Glendon, Horseshoe Bend, Deep River, 11 Jun 1960, Radford 43384 (NCU). Northampton Co.: $3 \mathrm{mi} \mathrm{W}$ of Boones Crossroads, Roanoke River, 31 May 1958, Ahles 41900 \& Duke (NCU, VDB). Orange Co.: Chapel Hill, 8 May 1897, Ashe 2008 (NCU). Randolph Co.: $4 \mathrm{mi}$ NE of New Hope, 24 May 1960, Radford 43016 (NCU, USCH). Wake Co.: $4 \mathrm{mi} \mathrm{N}$ of Bayleaf, near Neuse River, 22 May 1960, Radford 42922 (NCU, VDB).-OHIO. Adams Co.: 3 air mi NE of Peebles, 16 May 1994, Naczi 3874 (KNK*, MICH). Cuyahoga Co.: Parma, 18 May 1896, Watson s.n. (OS). Jackson Co.: Liberty Township, 19 May 1935, Bartley s.n. \& Pontius (OS). Pike Co.: 1.5 road mi W of Buchanan, 16 May 1994, Naczi 3887 (KNK*, MICH), 26 Aug 1995, Naczi 4976 \& Naczi (KNKs $)$. Summit Co.: Boston Township, E side of Cuyahoga River, 16 May 1991, McCormac 3547 \& Stoutamire (OS).-PENNSYLVANIA. Adams Co.: $1 \mathrm{mi} \mathrm{N}$ of Orrtanna, 9 Jun 1949, Wahl 6378 et al. (PAC, PENN). Bedford Co.: $1.5 \mathrm{mi}$ NNW of Imlertown, 21 Jun 1942, Berkheimer 3232 (NCU). Blair Co.: 0.4 mi ESE of Bellwood, 28 Jun 1982, Kunsman 4500 (PAC). Bradford Co.: $\sim 1.3 \mathrm{mi} \mathrm{NW}$ of Franklindale, S of Preacher Brook, 15 Jun 1990, Naczi 2608 (MICH ${ }^{*}$, $\mathrm{PH}$, US, VDB, ctb). Bucks Co.: $\sim 1.5 \mathrm{mi}$ NE of Richlandtown, 14 May 1921, Long 24101 (PH). Centre Co.: $1 \mathrm{mi} \mathrm{W}$ of Waddle along route 550, 13 Jun 1994, Naczi 4112 \& Thieret $\left(\mathrm{KNK}^{*}\right)$. Franklin Co.: $\sim 2.9 \mathrm{mi} \mathrm{S}$ of Upper Strasburg, 28 May 1992, Kunsman 10119 (PAC). Greene Co.: $1.5 \mathrm{mi} \mathrm{N}$ of Jefferson, 1 Jul 1940, Bell 250 (PENN). Huntingdon Co.: $1.8 \mathrm{mi} \mathrm{S}$ of Jo Hays Vista, 14 Jun 1985, Rettig 1313 (MICH*). Lancaster Co.: 2 mi NW of Blainsport, 1 Jul 1952, Schaeffer 39357 (PH). Lehigh Co.: Lehigh Furnace, 18 Jun 1916, Pretz 8163 (PH). Luzerne Co.: 2 mi NW of Conyngham, 10 Jun 1938, Wagner 6889 (PENN). Montour Co.: $1.5 \mathrm{mi}$ NW of Exchange, 11 Jun 1960, Berkheimer 20031 (PAC, PENN).SOUTH CAROLINA. York Co.: $\sim 4 \mathrm{mi} \mathrm{NW}$ of Bethany, 17 May 1996, Naczi 5312 (KNK, MICH, USCH, ctb).TENNESSEE. Clay Co.: $\sim 3.0 \mathrm{mi}$ W of Arcot Church, along Arcot Road, 29 Apr 1991, McNeilus 91-193 $\left(\mathrm{KNK}^{*}\right)$. Grainger Co.: $\sim 5 \mathrm{mi} \mathrm{NE}$ of Thorn Hill, 22 Jun 1993, Reznicek 9544 et al. (KNK*, MICH). Morgan Co.: Rugby, 28 May 1933, Underwood 1 ( $\left.\mathrm{MICH}^{*}\right)$. Scott Co.: $\sim 10$ air mi W of Oneida at route 297 crossing of Big South Fork of Cumberland River, 22 Jun 1993, Naczi 3201 \& Reznicek (KNK*).-VERMONT. Rutland Co.: Sudbury, 9 Jul 1919, Knowlton s.n. (MICH, MO).-VIRGINIA. Albemarle Co.: $1 \mathrm{mi}$ ENE of Monticello, 21 May 1980, Wieboldt M-134 (PH). Bland Co.: $1.5 \mathrm{mi} \mathrm{NE}$ of Mechanicsburg, 26 May 1983, Wieboldt 4682 (IBE). Fairfax Co.: 1.5 mi SE of Gradt Falls, near Difficult Run, 
7 May 1939, Hermann 10271 (MO, NA). Rockbridge Co.: Natural Bridge, 4 Jun 1891, Churchill s.n. (MO). Russell Co.: slopes of Clinch River at river mile 290.5, 21 Jun 1993, Reznicek 9533 et al. (KNK*, MICH). Scott Co.: $\sim 6$ mi NE of Gate City, W of route 669 crossing of Copper Creek, 21 Jun 1993, Naczi 3173 \& Reznicek $\left(\mathrm{KNK}^{*}\right)$.-WASHINGTON, D.C. Asylum grounds, 26 May 1889, Churchill s.n. (MO).-WEST VIRGINIA. Boone Co.: $1.5 \mathrm{mi} \mathrm{NW}$ of Nellis, 12 May 1993, Cusick 30839 (MICH). Hardy Co.: $2.5 \mathrm{mi} \mathrm{NE}$ of Baker, 28 May 1985, Cusick 24274 (MICH*, VDB). Lincoln Co.: $0.5 \mathrm{mi}$ SE of Sweetland, 12 May 1993, Cusick 30853 $(\mathrm{MICH})$.

\section{LITERATURE CITED}

ANDERSON, L. C. 1989. Noteworthy plants from north Florida. IV. Sida 13: 497-504.

BAILEY, L. H. 1886. A preliminary synopsis of North American Carices, including those of Mexico, Central America, and Greenland, with the American bibliography of the genus. Proceedings of the American Academy of Arts and Sciences 22: 59-157.

. 1889. Studies of the types of various species of the genus Carex. Memoirs of the Torrey Botanical Club 1: 1-85.

- 1894a. Carex. In Committee of the Botanical Club of the American Association for the Advancement of Science, List of Pteridophyta and Spermatophyta growing without cultivation in northeastern North America, 71-101. Memoirs of the Torrey Botanical Club 5: 1-377.

- 1894b. Carex. In J. M. Coulter [ed.], Manual of the phanerogams and pteridophytes of western Texas, 476-484. Contributions from the United States National Herbarium 2: 347-588.

Bоotт, F. 1858. Illustrations of the genus Carex, vol. 1. William Pamplin, London.

Cabe, P. R., AND C. Werth. 1995. The Trillium pusillum Michaux (Liliaceae) complex in Virginia. II. Isozyme evidence. Castanea 60: 15-29.

Catling, P. M., A. A. Reznicek, And W. J. Crins. 1993. Carex juniperorum (Cyperaceae), a new species from northeastern North America, with a key to Carex sect. Phyllostachys. Systematic Botany 18: 496-501.

CRINS, W. J. 1990. Phylogenetic considerations below the sectional level in Carex. Canadian Journal of Botany 68: 1433-1440.

DE SCHweinitz, L. D. 1825. A monograph of the North American species of Carex. Annals of the Lyceum of Natural History of New York 1: 283-374.

Dewey, C. 1825. Caricography. American Journal of Science and Arts 9: $257-263$.

Fenneman, N. M. 1938. Physiography of eastern United States. McGraw-Hill, New York, NY.

Fernald, M. L. 1950. Gray's manual of botany, 8th ed. American Book Co., New York, NY.

Ford, B. A., D. A. R. McQueEn, R. F. C. NACZi, AND A. A. ReZnicek. 1998. Allozyme variation and genetic relationships among species in the Carex willdenowii complex (Cyperaceae). American Journal of Botany 85: in press.

Gleason, H. A., AND A. Cronquist. 1991. Manual of vascular plants of northeastern United States and adjacent Canada, 2d ed. New York Botanical Garden, Bronx, NY.

Hermann, F. J. 1954. Addenda to North American Carices. American Midland Naturalist 51: 265-286.
. 1955. Two new carices from southeastern United States. Rhodora 57: 156-158.

Holm, T. 1900. Studies in the Cyperaceae XIII. Carex willdenowii and its allies. American Journal of Science, Fourth Series 10: 33-47.

Holmgren, P. K., N. H. Holmgren, and L. C. Barnett [eds.]. 1990. Index herbariorum part I. The herbaria of the world, 8th ed. New York Botanical Garden, Bronx, NY.

Johnson, G. P. 1988. Revision of Castanea sect. Balanocastanon (Fagaceae). Journal of the Arnold Arboretum 69: 25-49.

JoNES, A. G. 1979. A study of wild leek, and the recognition of Allium burdickii (Liliaceae). Systematic Botany 4: 29-43.

KARTESZ, J. T. 1994. A synonymized checklist of the vascular flora of the United States, Canada, and Greenland, 2d ed. Timber Press, Portland, OR.

KRAL, R. 1983. A report on some rare, threatened, or endangered forestrelated vascular plants of the south, vol. I. United States Department of Agriculture Forest Service, Atlanta, GA.

Kükenthal, G. 1909. Cyperaceae-Caricoideae. In A. Engler [ed.], Das Pflanzenreich, IV. 20, Heft 38, 1-824. Wilhelm Englemann, Leipzig.

KunTH, C. S. 1837. Enumeratio plantarum, vol. 2. J.G. Cotta, Stuttgart.

Little, E. L. 1977. Atlas of United States trees, vol. 4. United States Government Printing Office, Washington, DC.

MackenzIE, K. K. 1935. Cyperaceae-Cariceae. North American Flora 18: $169-478$.

McNeILus, V. B. 1992. Carex ouachitana (Cyperaceae) new to Tennessee. Sida 15: 154-155.

Mohlenbrock, R. H., AND J. Schwegman. 1969. A new species of Carex section Bracteosae. Brittonia 21: 77-79.

NACZI, R. F. C. 1993. Carex brysonii and Carex godfreyi, new species of Carex section Griseae (Cyperaceae) from the southeastern United States. Contributions from the University of Michigan Herbarium 19: 195-205.

PATRICK, T. S. 1984. Trillium sulcatum (Liliaceae), a new species of the southern Appalachians. Brittonia 36: 26-36.

Pirkle, E. C., AND W. H. Yoho. 1977. Natural regions of the United States, 2d ed. Kendall/Hunt, Dubuque, IA.

RezniceK, A. A. 1990. Evolution in sedges (Carex, Cyperaceae). $\mathrm{Ca}$ nadian Journal of Botany 68: 1409-1432.

SCORA, R. W. 1967. Interspecific relationships in the genus Monarda (Labiatae). University of California Publications in Botany 41: 159.

Soll Conservation Service. 1982. National list of scientific plant names, vol. 1. United States Government Printing Office, Washington, DC.

SteudEL, E. G. 1855. Synopsis plantarum cyperacearum. J. B. Metzler, Stuttgart.

ToRrey, J. 1836. Monograph of North American Cyperaceae. Annals of the Lyceum of Natural History of New York 3: 239-448.

WILKINSON, L. 1989. SYSTAT: the system of statistics. SYSTAT, Evanston, IL.

Willdenow, C. L. 1805. Species plantarum, vol. 4. G. C. Nauk, Berlin. Wofford, B. E. 1983. A new Lindera (Lauraceae) from North America. Journal of the Arnold Arboretum 64: 325-331.

\section{NOTE ADDED IN PROOF}

We recently examined a specimen of Carex willdenowii Willdenow that appears to be the first collection of this species from Missouri. The collection data for this specimen are U.S.A. MISSOURI. Reynolds Co.: $\sim 6 \mathrm{mi}$ $\mathrm{N}$ of Centerville, 12 May 1995, Summers 7351 (MO). 